\title{
A FÉ DE UM IMPÉRIO: A INQUISIÇÃO NO MUNDO PORTUGUÊS DE QUINHENTOS
}

\author{
Giuseppe Marcocci
}

Doutor em História Moderna e investigador na

Scuola Normale Superiore de Pisa - Itália

\section{Resumo}

O artigo apresenta a primeira tentativa de reconstrução das estratégias de difusão do tribunal da Inquisição nas diferentes regiões do Império português durante o século XVI. Em particular, pretende-se estudar a formação de uma visão global do império nas autoridades centrais do Santo Ofício, as ligações entre Inquisição e expansão colonial, os modelos de atuação dos inquisidores e as suas relações com os outros agentes eclesiásticos, nomeadamente os bispos e os missionários.

\section{Palavras-chave}

Inquisição • Império português • Igreja missionária.

\section{Correspondência}

Scuola Normale Superiore

Piazza dei Cavalieri, 7

56126 - Pisa - Itália

E-mail: g.marcocci@sns.it 


\title{
FAITH AND EMPIRE: \\ THE INQUISITION IN THE SIXTEENTH-CENTURY \\ PORTUGUESE WORLD
}

\author{
Giuseppe Marcocci \\ Ph.D.in Social History of \\ Scuola Normale Superiore de Pisa - Italy.
}

\begin{abstract}
This article attempts to reconstruct for the first time the strategies of propagation of the Inquisition in the different regions of the sixteenth-century Portuguese empire. In particular, it will be analysed the shaping of a global view of the empire by the central authorities of the Holy Office, the connections between Inquisition and colonial expansion, the patterns of activity of the inquisitors, as well as their relationship with other ecclesiastic agents, starting from bishops and missionaries.
\end{abstract}

\section{Keywords}

Inquisition • Portuguese Empire • Missionary Church.

\section{Contact}

Scuola Normale Superiore

Piazza dei Cavalieri, 7

56126 - Pisa - Italy

E-mail: g.marcocci@sns.it 


\section{Uma só fé: o mundo visto de Lisboa}

$\mathrm{Na}$ Lisboa da segunda metade de Quinhentos, uma conversa em frente a um mapa-mundi podia converter-se numa disputa sobre questões de fé. Assim aconteceu a 29 de maio de 1573. Em casa do prior da igreja de São Nicolau, Afonso Teles de Meneses, era hóspede um gentil-homem arruinado de Évora: a figura emagrecida pela idade, o rosto "que lhe luze", Pedro Correia gabava-se de ter viajado na Europa das guerras de religião e de manter relações com ilustres teólogos do reino; tinha também impresso um pequeno livro de conteúdo espiritual sem licença da Inquisição. Naquele dia, contemplando um planisfério possuído pelo prior, pousou o olhar sobre a parte do globo "onde estava pintado o senhorio do preste Joam e estava nelle pintada huma crux". Aquele símbolo universal ofereceu a Correia o motivo para uma aberta defesa da cristandade dispersa pelo mundo, que acabou por se traduzir na avaliação das diferenças exteriores entre distintas confissões. Era uma atitude conciliadora, que respondia às dúvidas que desde há algum tempo, em Portugal, circundavam a ortodoxia dos etíopes observantes de uma variante do culto monofisista copto e tradicionalmente identificados com os súditos do legendário soberano. Correia parecia reagir ao firme fechamento ao cristianismo oriental, sancionado agora pelas autoridades eclesiásticas lusitanas. Lançou-se então num aberto elogio da Reforma, atacando o celibato eclesiástico, proibições alimentares e, sobretudo, a confissão sacramental, além de dar crédito ao rumor de que os luteranos praticavam a comunhão dos bens. Em Lisboa, estava ainda fresca a memória da queima do "luterano" Manuel Travaços (1571), mas também do processo movido com a mesma acusação, por fatos que remontavam a mais de trinta anos antes, contra o ancião e aclamado humanista Damião de Góis (1571-1572). O prior Teles de Meneses não perdeu tempo: apresentou uma denúncia que levou a Inquisição a ordenar um inquérito, cedo arquivado pela morte de Correia entretanto ocorrida. ${ }^{1}$ Mas de interesse aqui é, acima de tudo, o movimento intelectual deste último no qual se refletia uma capacidade nova de por em relação as muitas formas de uma geografia religiosa do mundo, cuja cada

\footnotetext{
1 Denúncia apresentada por Afonso Teles de Meneses, 4 junho de 1573 (Arquivo Nacional da Torre do Tombo [ANTT]. Inquisição de Lisboa [IL], Livro 56, fls. 237-241v). Sobre os casos judiciais a que se faz referência cf. PEREIRA, Isaías da Rosa. O processo de Manuel Travaços na Inquisição de Lisboa (1570-1571) e a prisão de Damião de Góis. Anais da Academia Portuguesa da História 36, 1998, p. 157-173; e PAIVA, José Pedro. Católico sou e não luterano. O processo de Damião de Góis na Inquisição (1571-1572). In: SERRÃO, José Vicente (coord.). Damião de Góis. Um humanista na Torre do Tombo. Lisboa: IAN/TT, 2002, p. 20-42.
} 
vez mais madura consciência distinguia a capital do extenso, mas descontínuo, império colonial construído pelos portugueses em África, Ásia e Brasil.

Sob a escolta de Serge Gruzinski, não é difícil imaginar como de Lisboa fosse então verdadeiramente possível pensar em contemplar o entrelaçado do mundo, nas suas distâncias e nas suas diferenças físicas, como na variedade de costumes e crenças dos povos que nele habitavam. ${ }^{2}$ Mas o olhar de Correia não era totalmente inocente. Ele conservava a memória do silencioso conflito sobre a fé dos etíopes que havia percorrido a cultura lusitana nos decênios precedentes. Um ponto de não retorno fora transposto com a falhada tentativa de promover uma estratégia de conciliação no plano religioso, elaborada pelo humanista Damião de Góis. No ano de 1540, tinha publicado um tratado no qual exortava a reconhecer a substancial ortodoxia do cristianismo etíope. No destino daquela obra, alcança-se o ocaso do objetivo mais amplo de uma reunificação consensual entre a Sé apostólica e as igrejas orientais no seio de um triunfo missionário do Império português. Aparecida em Lovaina, após ser examinada pelos censores do Santo Ofício lusitano, a circulação da Fides, Religio Moresque foi proibida em Portugal (1541). O escrito de Góis tinha sido composto no calor da lição de Erasmo e era sustentado por profecias que viam no iminente retorno à unidade da Igreja das origens (a chegada dos portugueses à Etiópia era disto um anúncio) o sinal da natureza milenarista de um império escolhido para guiar a conversão universal dos povos e o aniquilamento do secular inimigo muçulmano. Foi refutado, entre outros, pelo severo teólogo Pedro Margalho, uma figura central na definição das orientações religiosas em Portugal, inclusivamente no advento da Inquisição no reino (1536). ${ }^{3}$ Com o bloco de teólogos e conselheiros em matéria de religião que se impuseram na corte de João III entre os finais dos anos 1520 e o início dos anos 1530, aquele intransigente homem da Igreja, que se formara em Paris e tinha disputado a Cátedra de Prima com Francisco de Vitoria em Salamanca (para além de reprovar as teses de Erasmo na junta de Valladolid, em 1527), contribuiu de forma determinante para o enfraquecimento dos tons de entusiasmo pelos sucessos da evangelização pelo retomar de contatos com o cristianismo oriental, por temor de que pudessem conduzir a um amolecimento

\footnotetext{
GRUZNSKI, Serge. Les quatre parties du monde. Histoire d'une mondialisation. Paris: Martinière, 2004.

3 Permito-me reenviar para o meu estudo: MARCOCCI, Giuseppe.Gli umanisti italiani e l'impero portoghese: una interpretazione della Fides, Religio, Moresque Athiopum di Damião de Góis [2005]. In: LUPETTI, Monica (cura). Traduzioni, imitazioni, scambi tra Italia e Portogallo nei secoli. Firenze: Olschki, 2008, p. 61-124.
} 
em relação aos erros de fé. ${ }^{4}$ Em Portugal, a rígida aderência à ortodoxia católica transformou-se, assim, num agressivo critério de distinção e de segregação, que favoreceu a criação do Santo Ofício e o nascimento de uma censura organizada, bem como uma rápida clericalização da vida política e cultural do reino. ${ }^{5}$ Cristãos de rito não católico e convertidos de diversas origens foram assim todos envolvidos numa suspeita geral, que os transformou, em seguida, no alvo privilegiado da Inquisição. Em pouco tempo, num reino cuja uniformidade religiosa era produto da conjunta conversão em massa dos judeus e da expulsão dos muçulmanos nos finais de Quatrocentos, difunde-se a tendência de perceber em cada mínimo desvio um atentado à integridade da fé. Aquele processo complicou-se num jogo de espelhos entre o contexto ibérico e europeu de um lado e, do outro, uma representação da pluralidade religiosa do mundo reduzida à oposição entre "infiéis" (categoria em que os muçulmanos eram considerados como um adversário quase irredutível) e cristãos (fiéis de outras Igrejas, ou conversos). Entre referências explícitas e alusões indiretas estabeleceu-se um paralelo entre frente interna, caracterizada por uma conspícua presença de judeus convertidos - os chamados "cristãos-novos" -, mas também de "luteranos" (adjetivo aplicado, sem grandes cuidados, seja aos erasmianos, seja aos sequazes da Reforma, na sua complexidade), e frente externa: aos dois primeiros grupos corresponderiam, com múltiplas variantes na sua irredutível diversidade, os novos convertidos de origem asiática, africana ou americana, de um lado, os cristãos orientais do outro. ${ }^{6}$

A comum acusação de heresia revestiu-se de um conjunto amplo e disforme de crenças e de comportamentos, como demonstrou a própria recepção do tratado de Góis em Portugal: a sua proibição foi justificada ao autor com o risco de que os cristãos-novos do reino retirassem convicções errôneas da excessiva abertura da Fides; todavia, como notava já Marcel Bataillon, a inquietar os inquisidores, que sabiam dos contatos de Góis com expoentes de proa da Reforma (de Lutero a Melanchton), deviam estar também as aparentes analogias entre aspectos do cristianismo etíope e doutrinas reconduzíveis ao mundo protestante (do matri-

4 Apologético, mas útil, SOARES, Luís Ribeiro. Pedro Margalho. Lisboa: INCM, 2000. À luz de figuras como Margalho, parece-me que se compreende melhor também a magistral reconstrução de AUBIN, Jean. Le prêtre Jean devant la censure portugaise [1980]. In: Idem. Le latin et l'astrolabe. Lisboa: CNCDP-Centre Culturel Calouste Gulbenkian, 1996-2006, vol. 1, p. 183-210.

5 Para uma análise mais aprofundada ver o meu artigo: MARCOCCI, Giuseppe. A fundação da Inquisição portuguesa: um novo olhar. Lusitania Sacra, 2a s., 22, 2010 (no prelo).

6 Nisto insistiu primeiramente, partindo do confronto entre cristãos-novos e indianos convertidos, XAVIER, Ângela Barreto. De converso a novamente convertido. Identidade política e alteridade no Reino e no Império. Cultura. Revista de Teoria e História das Ideias, 22, 2006, p. 245-275. 
mônio de sacerdotes à reiteração do batismo). ${ }^{7}$ Não foi então um acaso que, na origem daquela condenação, se encontrasse o próprio Margalho que, já num tratado de 1520, tinha liquidado os cristãos orientais como heréticos, precisando depois que os etíopes "admitem heresias e falsos dogmas, observam os preceitos da Lei Velha com a nossa e imitam os costumes dos outros infiéis".

É raro encontrar nas fontes lusitanas de início de Quinhentos a palavra "heresia" referida às igrejas orientais das quais Roma e a Europa tinham estado separadas durante séculos. A redescoberta daquela cristandade de traços místicos (do preste João aos cristãos de são Tomás) tinha alimentado, desde a metade do século anterior, a retórica oficial de um expansionismo colonial português ainda em busca de legitimação. ${ }^{9}$ Mas, tons de amarga desilusão não tardaram a emergir. Por volta de 1530, Álvaro Penteado, missionário português em Kerala, rotulou os habitantes cristãos, que se pretendiam descendentes dos convertidos do apóstolo Tomás, como nestorianos ("Nestor, cuja seita e erro seguem"). ${ }^{10}$ Penteado tinha inaugurado por isso o uso de lhes administrar um segundo batismo, uma prática que, em meados de Quinhentos, foi muitas vezes retomada por missionários e alargada aos cristãos orientais em geral, contra quem as autoridades lusitanas nutriam agora um total juízo negativo: de potenciais aliados na guerra contra os infiéis, tornaramse, deste modo, nos destinatários de uma política de conversão e de controle. ${ }^{11}$

\section{Marcas para uma história global da Inquisição no Império português}

A par da anulação violenta das minorias judia e muçulmana do reino de Portugal em finais do século XV, a gradual intransigência face às igrejas orientais é um fator que, talvez subvalorizado, se reveste de uma importância decisiva para

7 BATAILlON, Marcel. Le cosmopolitisme de Damião de Góis [1938]. In: Idem. Études sur le Portugal au temps de l'humanisme. Paris: Fundação Calouste Gulbenkian-Centro Cultural Português, 1974, ${ }^{2}$ p. 121-154: 149-150.

8 "hereses et falsa admittunt dogmata et legalia veteris legis cum nostra observant aliosque infideles mores imitantur". MARGALHO, Pedro. Phisices Compendium. Salmantice, 1520, fls. iiijrv.

9 ROGERS, Francis M. The quest for Eastern christians. Travels and rumor in the age of discovery. Minneapolis: Minnesota University Press, 1962.

${ }^{10}$ Carta ao cardeal infante d. Afonso, s.d. [ca. 1529-1530]. In: Documentação para a história do padroado português do Oriente. Índia. Coligido e anotado por António da Silva Rego. Lisboa: Fundação Oriente-CNCDP, 1991-2000, ${ }^{2}$ vol. 2, doc. 108. Atenua o tom de reprovação THOMAZ, Luís Filipe F. R. Were Saint Thomas christians looked upon as heretics? In: MATHEW, K. S.; SOUZA, Teotónio R. de; MALEKANDATHIL, Pius (ed.). The Portuguese and the socio-cultural changes in India, 1500-1800. Tellicherry: Fundação Oriente-Meshar, 2001, p. 27-91, p. 35.

${ }^{11}$ Exemplar o tratamento reservado aos escravos etíopes em Ormuz pelo jesuíta Kaspar Berzé, que se discute numa carta de 1 de dezembro de 1549: WICKI, Josef e CORREIA, John (ed.). Documenta Indica [DI]. Roma: Institutum Historicum Societatis Iesu, 1948-1988, vol. 1, doc. 87A. 
compreender a fundo a evolução da relação entre os portugueses e as regiões não europeias e, no meio disto, a tortuosa história das estratégias de evangelização no império lusitano. ${ }^{12} \mathrm{Na}$ elaboração do ideal de reduzir a um modelo uniforme de catolicismo a excepcional variedade que caracteriza os mundos a que os portugueses acederam, a Inquisição ofereceu também um contributo.

A ação concreta do Santo Ofício lusitano nas regiões do ultramar gozou de um constante, mas desigual interesse historiográfico. Subsiste o paradoxo de uma forte diferença entre a abundância de investigações sobre o Brasil, onde porém os inquisidores tardaram a penetrar e não tiveram nunca uma sede estável, e as tímidas pesquisas sobre o Estado da Índia, a unidade administrativa que compreendia os territórios do Império português disseminados entre a África Oriental e o Sudeste asiático, sujeita, pelo contrário, desde 1560 a uma Inquisição com sede na capital Goa. ${ }^{13}$

Os trabalhos de José Gonçalves Salvador e de Anita Novinsky sobre os cristãos-novos, as principais vítimas do Santo Ofício na colônia lusitana na América, abriram um caminho longo no qual se inseriram desde então estudiosos sensíveis também aos aspectos institucionais da presença da Inquisição no Brasil na Idade Moderna, de Sônia Siqueira a Bruno Feitler; enquanto que Ronaldo Vainfas trouxe luz à centralidade do controle exercido sobre a esfera da sexualidade. ${ }^{14}$ Sobre o tribunal lusitano na Índia, pelo contrário, continua ainda fundamental a monografia dedicada por António Baião, na primeira metade do século passado, à sua organização interna e ao seu funcionamento. ${ }^{15}$ Charles Amiel teve depois o

${ }^{12}$ Sobre as consequências do édito de expulsão de judeus e de muçulmanos ver SOYER, François. The persecution of the Jews and the Muslims of Portugal. King Manuel and the end of religious tolerance, 1496-7. Leiden-Boston: Brill, 2007. Sobre as discussões que se seguiram à conversão dos judeus, permito-me reenviar para o meu estudo: MARCOCCI, Giuseppe.“... per capillos adductos ad pillam". Il dibattito cinquecentesco sulla validità del battesimo forzato degli ebrei in Portogallo (1496-1497). In: PROSPERI, Adriano (cura). Salvezza delle anime, disciplina dei corpi. Un seminario sulla storia del battesimo. Pisa: Edizioni della Normale, 2006, p. 341-423.

${ }^{13}$ A hipótese de abrir um tribunal no Brasil foi discutida no tempo da dominação espanhola; ver FEITLER, Bruno. Usos políticos del Santo Oficio portugués en el Atlántico (Brasil y África Occidental). El período filipino. Hispania Sacra, 59, 2007, p. 269-291.

${ }^{14}$ SALVADOR, José Gonçalves. Cristãos-novos, jesuitas e Inquisição. Aspectos da sua atuação nas capitanias do Sul, 1530-1680. São Paulo: Livraria Pioneira, 1969; NOVINSKY, Anita. Cristãos novos na Bahia. São Paulo: Perspectiva, 1972; SIQUEIRA, Sônia A. A Inquisição portuguesa e a sociedade colonial. São Paulo: Ática, 1978; VAINFAS, Ronaldo. Trópico dos pecados. Moral, sexualidade e Inquisição no Brasil. Rio de Janeiro: Campus, 1989; FEITLER, Bruno. Inquisition, juifs et nouveaux-chrétiens au Brésil. Le Nordeste, XVII ${ }^{e}-X V I I I^{e}$ siècles. Leuven: Leuven University Press, 2003. Também se insere nesta tradição PEREIRA, Ana Margarida Santos. $A$ Inquisição no Brasil. Aspectos da sua atuação nas capitanias do Sul, de meados do séc. XVI ao início do séc. XVIII. Coimbra: Faculdade de Letras da Universidade de Coimbra, 2006.

${ }^{15}$ BAIÃO, António. A Inquisição de Goa. Lisboa: Academia das Ciências, 1930-1945. Útil também a síntese, editada postumamente (o texto remonta a 1965), de RÉVAH, Israël-Salvator. Pour l'histoire 
mérito de iluminar os traços principais da história do Santo Ofício de Goa, apesar da perda quase total dos processos. ${ }^{16}$ Como demonstrou Ana Isabel Cannas da Cunha, a expansão da Inquisição até às costas do oceano Índico foi determinada pelo objetivo de atingir os cristãos-novos que tinham procurado refúgio nos maiores centros do Império português. ${ }^{17}$ Por isso, os historiadores encontram informações preciosas sobre o tribunal de Goa também nos estudos de James Boyajian, especialista nas redes comerciais internacionais, e de José Alberto Tavim, especialista na diáspora sefardita. ${ }^{18} \mathrm{O}$ Santo Ofício deu provas também na Ásia de concentrar a repressão mais dura sobre os judaizantes, a categoria a que foi infligido, de longe, o maior número de condenações à morte; e todavia, a atividade quotidiana dos inquisidores de Goa foge ainda aos historiadores, uma vez que não se alarga o campo de investigação aos outros delitos perseguidos segundo estratégias mutáveis, a partir da apostasia dos hindus convertidos (gentilidade), o delito que mais ocupou os magistrados de um tribunal da fé empenhado também em estimular uma política de anulação da prática pública dos cultos locais, como observava já há meio século Anant Priolkar. ${ }^{19}$

A Inquisição portuguesa teve, além disso, autoridade sobre algumas regiões costeiras do continente africano, onde interveio com procedimentos e eficácia desiguais. Se, para Marrocos, se dispõe de uma sólida monografia de José Alberto Tavim sobre a comunidade de judeus e de cristãos-novos, como quase em todo lado o grande alvo do Santo Ofício lusitano, tempos e formas das incursões inquisitoriais na África sub-saariana, episódicas mas não inócuas, beneficiaramse das pesquisas de estudiosos como José da Silva Horta e Peter Mark. ${ }^{20}$ Pronto

religieuse de l'Asie portugaise: l'activité du tribunal de Goa. In: Memorial I.-S. Révah, p. 545-560.

${ }^{16}$ AMIEL, Charles. L'Inquisition de Goa. Survol historique. In: L'Inquisition de Goa. AMIEL, Charles e LIMA, Anne (ed.). La relation de Charles Dellon (1687). Paris: Chandeigne, 1997, p. 61-74; AMIEL, Charles. L'Inquisition de Goa. In: BORROMEO, Agostini (cura). L'Inquisizione. Atti del simposio internazionale. Città del Vaticano: Biblioteca Apostolica Vaticana, 2003, p. 229-250.

${ }^{17}$ CUNHA, Ana Isabel Cannas da. A Inquisição no Estado da Índia. Origens (1539-1560). Lisboa: ANTT, 1995.

${ }^{18}$ BOYAJIAN, James C. Goa Inquisition. A new light on the first 100 years (1561-1660). Purabhilekh-Puratatva, 4, 1986, p. 1-40; Idem. Portuguese trade in Asia under the Habsburgs, 1580-1640. Baltimore-London: The Johns Hopkins University Press, 1993; TAVIM, José Alberto R. S. Judeus e cristãos-novos de Cochim. História e memória, 1500-1662. Braga: APPACDM, 2003. Sem qualquer utilidade GINIO, Alisa Meyuhas. The Inquisition and the new christians: the case of the Portuguese Inquistion of Goa. The Medieval History Journal, 2, 1999, p. 1-18.

${ }^{19}$ PRIOLKAR, Anant K. The Goa Inquisition. Being a Quatercentenary Commemoration Study of the Inquisition in India. Bombay, 1961, p. 114-149. Para um rápido balanço sobre a perseguição aos hindus ver AMIEL, Charles. L'Inquisition de Goa. Survol historique, p. 71-72.

${ }^{20}$ TAVIM, José Alberto R. S. Os judeus na expansão portuguesa em Marrocos durante o século XVI. Origens e actividades duma comunidade. Braga: APPACDM, 1997. De José da Silva Horta 
a perseguir os judaizantes nos entrepostos do comércio colonial, o tribunal foi capaz de alargar o raio de ação até atacar também as crenças dos africanos convertidos pelos missionários, como se conclui da leitura das atas de um precioso colóquio de 2003, que marcou um passo importante para uma nova imagem do impacto da Inquisição em África. ${ }^{21}$

A tendência para superar a tradicional separação dos estudos sobre áreas geográficas particulares onde operou o Santo Ofício emergiu em meados dos anos noventa do século passado, sem que, no entanto, se encontrassem investigadores dispostos a cultivá-la e aprofundá-la. O livro de Francisco Bethencourt sobre três inquisições modernas contribuiu para um olhar mais alargado sobre os tribunais apostólicos delegados no mundo católico entre os finais de Quatrocentos e os inícios de Oitocentos. A sua análise cruza em diversos momentos as características da atividade inquisitorial nos territórios imperiais portugueses, às vezes acercando os diversos contextos no sentido de chegar a uma primeira comparação entre os modelos que aí se impuseram. Muitas vezes preciosas, as considerações de Bethencourt ficam, no entanto, dispersas no interior de uma obra de caráter mais geral e não chegam a fundir-se numa síntese compacta. ${ }^{22}$ Sobre as regiões do padroado da coroa lusitana, pelo contrário, concentra-se, de modo específico, um artigo de Caio Boschi que tem o mérito de introduzir os casos da Inquisição depois de ter resumido a extensão da rede eclesiástica diocesana e missionária no Império. E, todavia, os diversos aspectos são apenas justapostos, sem indagar as suas conexões profundas; e a parte sobre o tribunal da fé, embora correta, é limitada por uma rígida distinção entre âmbitos territoriais. ${ }^{23}$

ver HORTA, José da Silva. Africanos e portugueses na documentação inquisitorial de Luanda a Mbanza Kongo (1596-1598). In: ENCONTRO DE POVOS E CULTURAS EM ANGOLA. Actas do seminário. Lisboa: CNCDP, 1997, p. 301-321; é autor de estudos a quatro mãos com Peter Mark, entre os quais HORTA, José da Silva e MARK, Peter.Two early seventeenth-century Sephardic communities on Senegal's. Petite Côte. History in Africa, 31, 2004, p. 231-256; e Duas comunidades sefarditas na costa norte do Senegal no início do século XVII: Porto de Ale e Joala. In: BARRETO, Luís Filipe et. al. (coord.). Inquisição portuguesa. Tempo, razão e circunstância. Lisboa-São Paulo: Prefácio, 2007, p. 277-304. Ver também GREEN, Tobias. Further considerations on the Sephardim of the Petite Côte. History in Africa, 32, 2005, p. 165-183.

${ }^{21}$ BETHENCOURT, Francisco e HAVIK, Philip (org.). Inquisição em África. Revista Lusófona de Ciência das Religiões, 3, 2004, p. 21-173. O ensaio de Filipa Ribeiro da Silva retoma a inédita tese de mestrado da autora sobre a Inquisição entre Cabo Verde, Guiné e ilha de São Tomé e Príncipe (2002), à qual não tive acesso.

${ }^{22}$ BETHENCOURT, Francisco. História das Inquisições. Portugal, Espanha e Itália. Lisboa: Círculo de Leitores, 1994.

${ }^{23}$ BOSCHI, Caio. Estruturas eclesiásticas e Inquisição. In: BETHENCOURT, Francisco e CHAUDURI, Kirti (dir.). História da expansão portuguesa. Lisboa: Círculo de Leitores, 1998, vol. 2, p. 429-452. 
Num panorama constelado de estudos de indubitável qualidade, continua-se a descurar o nó que ligou Inquisição e conquista. $\mathrm{O}$ vazio de conhecimento, que aqui não se pretende certamente colmatar, não explica, no entanto, a falta de uma assunção, por parte dos historiadores, de uma perspectiva global. Se o tempo para uma síntese completa da história do Santo Ofício no Império português não parece ainda maduro, o presente contributo centrar-se-á na adaptação de um tribunal europeu nascido com uma função antijudaizante aos diferentes contextos do ultramar lusitano. Que razões ditaram as formas que a Inquisição assumiu no império? Existia uma linha que as unia? Em que modelos foram inspiradas? Que peso teve a experiência ibérica, não só portuguesa? E ainda: como se relacionou o tribunal da fé com os agentes da Igreja missionária? São perguntas de resposta inesperada, sobretudo se se exploram as conexões entre as soluções adotadas nas várias áreas do império lusitano numa estreita relação com as decisões tomadas em Lisboa e, em menor grau (pelo menos no século XVI), em Roma. Entre as questões à espera de serem afrontadas de forma preliminar, está, antes de mais nada, a da emergência de uma visão unitária, à escala mundial, do objetivo de vigiar a ortodoxia no espaço imperial português entre as autoridades centrais da Inquisição no reino; e, em segundo lugar, a identificação de algumas constantes nas todavia mutáveis estratégias de ação de um tribunal com um papel especial no projeto imperial lusitano.

\section{Inquisição e império: nas origens de uma expansão (ca. 1545-1560)}

No primeiro difícil decênio de atividade do Santo Ofício, os inquisidores de Lisboa receberam denúncias relativas ao Brasil e ao norte de África, estas últimas relacionadas sobretudo com apostasia de judeus convertidos retornados à sua religião original. ${ }^{24}$ Entre os vários documentos, no entanto, ressalta sobretudo a petição enviada em finais de 1546 pelos conselheiros municipais da ilha de Santiago, no arquipélago de Cabo Verde: aí se acusava um grupo de cerca de duzentos cristãos-novos portugueses de terem encontrado refúgio em terra firme, vivendo entre os africanos da costa, onde não só teriam tornado às práticas públicas das "cerimônias mosaicas", mas teriam cedido aos cultos locais e à poligamia. ${ }^{25}$ No vazio de autoridade causado pela morte do bispo Jean Petit (talvez provido de

${ }^{24}$ Vários exemplos são referidos em BAIÃO, António. A Inquisição em Portugal e no Brasil. Subsídios para a sua história. Lisboa: Edições do Arquivo Histórico Português, 1920, passim.

${ }^{25}$ ANTT. Inquisição de Évora [IE], Livro 588, fls. 8-11v (descoberto por MOTA, Adelino Teixeira da. Alguns aspectos da colonização e do comércio marítimo dos portugueses na África ocidental nos séculos XV e XVI. Lisboa: Junta de Investigações Científicas do Ultramar, 1976, p. 15). 
uma delegação inquisitorial da qual, em qualquer caso, não fez uso), os pedidos de uma intervenção do Santo Ofício permaneceram inatendidos. ${ }^{26} \mathrm{O}$ tribunal encontrava-se ainda na fase mais delicada de uma disputa com a Sé apostólica sobre os procedimentos seguidos com os cristãos-novos, que tinha já forçado a Inquisição a suspender a execução das sentenças (1544). De fato, foi só depois do acordo com Roma do definitivo reconhecimento dos plenos poderes (1547) que, em conjunto com os seus mais fiéis colaboradores (o dominicano Jéronimo de Azambuja e os canonistas Ambrósio Campelo e Jorge Gonçalves Ribeiro), o cardeal infante d. Henrique, irmão de d. João III (1521-1557) e inquisidor geral a partir de 1539, iniciou a projetar uma extensão efetiva do raio de ação do tribunal da fé para além dos confins do reino. ${ }^{27}$

Um primeiro momento de viragem ocorreu por volta de 1550, quando um Santo Ofício aparentemente débil, reduzido a apenas duas sedes (contra as seis que tivera nos anos quarenta), apostou com convicção no alargamento da competência geográfica dos inquisidores de Lisboa, que vigiavam também o interior do território de Portugal, excluindo a arquidiocese de Évora, que mantinha o seu próprio tribunal local. ${ }^{28}$ Foi então, de fato, que a Inquisição reivindicou expressamente uma jurisdição sobre as possessões da Coroa lusitana no norte de África e sobre os arquipélagos da Madeira, Cabo Verde e São Tomé. ${ }^{29}$ Aquela política de projeção atlântica foi inaugurada nos mesmos meses em que o tribunal emergia como uma arma privilegiada para reconduzir os humanistas mais inquietos para os limites da ortodoxia doutrinária, que devia constituir o único fundamento da cultura oficial de um reino amparado na missão de construir um império católico pelo mundo. Disto colhem-se marcas evidentes na prisão dos professores do Colégio das Artes de Coimbra, em agosto de 1550, como nos novos depoimentos contra Góis feitos no Santo Ofício de Lisboa pelo provincial jesuíta Simão Rodrigues (os primeiros

${ }^{26}$ A expressão usada pelos conselheiros de Santiago ("Com a vinda do bispo Dom Joham Parvy a estas Ilhas ficamos providos da Samta Inquisição sobre a qual lhe tinhamos tantas vezes esprito") deixa supor que Petit tivesse tido especial delegação inquisitorial.

${ }^{27}$ Os poderes de Azambuja, Campelo e Gonçalves Ribeiro foram definidos, uma primeira vez, por um decreto inquisitorial de 15 de outubro de 1549 (PEREIRA, Isaías da Rosa. Documentos para a história da Inquisição em Portugal, século XVI. Lisboa: Cáritas Portuguesa, 1987, doc. 3).

${ }^{28}$ A competência do tribunal de Lisboa foi clarificada por um decreto inquisitorial de 8 de maio de 1551 (ivi, doc. 2), emitido em favor de Campelo, Gonçalves Ribeiro e do frade dominicano Jorge de Santiago (ivi, doc. 28).

${ }^{29}$ SILVA, Filipa Ribeiro da. A Inquisição na Guiné, nas ilhas de Cabo Verde e São Tomé e Príncipe. In: Inquisição em África, p. 157-173: 158. Com o decreto de 4 de agosto de 1552, o cardeal infante d. Henrique confirma que os inquisidores de Lisboa tinham jurisdição sobre "pessoas de toda las partes destes reinos e senhorios deles e das Ilhas" (ivi, doc. 23). 
remontavam a 1545). Todos foram acusados de "luteranismo". ${ }^{30}$ Mas quão ampla pudesse ser a acepção daquela heresia, na mente dos inquisidores portugueses, é revelado no processo do cronista régio português Fernão de Pina, deposto do cargo depois de ser condenado, a 31 de março de 1550, a abjurar os seus erros, entre os quais a ideia de que "aquelas pesoas que não teverão noticya da ley de Christo como avya muitas terras omde nam foram os apóstolos, que estas pesoas se salvarião posto que não recebessem a agoa do bautismo". ${ }^{31}$

Foi numa data contida entre o fim da causa contra Pina e o início daquela contra os docentes de Coimbra que os mesmos juízes de Lisboa transmitiram, ao juiz civil do Funchal, Fernando Cardoso, a faculdade de indagar e de proceder às prisões em Ponta do Sol, na ilha da Madeira, no caso de "delytos de heresias e apostasias, feytiçarias, blasfemias e sortilegios e outros crimes asy tocamtes a Samta Imquisição, como a jurdição eclesiastica ordinaria", e também de delitos "que são da jurdição ordinária que não pertencem a Samta Imquisição" em virtude de um "especial poder" que lhes foi concedido pelo cardeal infante d. Henrique e pelo núncio apostólico Pompeo Zambeccari. ${ }^{32}$ Aquela delegação singular num magistrado secular era acompanhada por um regulamento no qual se inseriram medidas para limitar os riscos de usos arbitrários por parte de Cardoso, o qual foi proibido de encarcerar suspeitos na ausência de pelo menos três testemunhas (contra as duas habituais). ${ }^{33}$ Por norma, à semelhança do reino, também no espaço atlântico se procurou a colaboração do clero diocesano, com a emissão de procurações que permitissem aos representantes dos bispos do ultramar procederem ao envio dos presos para o tribunal de Lisboa. ${ }^{34} \mathrm{E}$, todavia, nos primeiros passos da nova estratégia imperial, colhe-se o eco do incômodo, então amadurecido em Portugal, dos inquisidores em relação a uma atividade autônoma da justiça epis-

${ }^{30}$ BRANDÃO, Mário. A Inquisição e os professores do Colégio das Artes. Coimbra: Imprensa da Universidade, 1949-1968, 2 vols. Rodrigues foi convocado a 24 de setembro de 1550 pela Inquisição de Lisboa para confirmar as declarações de 1545: tudo foi depois unido aos autos processuais (HENRIQUES, Guilherme J. C. Inéditos goesianos. Arruda do Vinhos: Arruda Editora, 2002, ${ }^{2}$ vol. 2).

${ }^{31}$ Denúncia do clérigo Jorge Manuel, 12 de março de 1545 (ANTT. IL, proc. 12.091, fls. 26v-27).

${ }^{32}$ Provisão de 22 de julho de 1550 (ANTT. IL, liv. 840, fls. 2-3). As concessões do inquisidor geral e do núncio encontram-se em PEREIRA. Documentos, docs. 67-68.

${ }^{33}$ A 26 de julho de 1550, o regimento (ANTT. IL, liv. 840, fls. 3-4v) foi consignado pessoalmente a Cardoso por Campelo e Gonçalves Ribeiro. Uma síntese sobre a presença do Santo Ofício está em SIQUEIRA, Sônia A. O Santo Ofício e o mundo atlântico: ação inquisitorial na Madeira. In: VAINFAS, Ronaldo; FEITLER, Bruno; LAGE, Lana (org.). A Inquisição em xeque. Temas, controvérsias, estudos de caso. Rio de Janeiro: Eduerj, 2006, p. 13-24.

${ }^{34}$ Para o reino cf. PAIVA, José Pedro. Les évêques et l'Inquisition portugaise, 1536-1613. In: AUDISIO, Gabriel (dir.). Inquisition et pouvoir. Aix-en-Provence: Publications de l'Université de Provence, 2004, p. 147-169. 
copal. ${ }^{35}$ Disso é prova a insistência sobre a "jurdição ordinaria" na delegação para a Madeira. ${ }^{36}$ Uma confirmação provém do caso de Cabo Verde, onde, em 1551, o vigário geral local, Gaspar Silveira, suscitou a profunda irritação do cardeal infante d. Henrique por ter-se intrometido, sem mandato, "em algumas cousas que tocavão ao Santo Officio da Imquisyção". Apesar do global entendimento entre o Santo Ofício e as autoridades diocesanas no mundo português, tratava-se de um ponto que se devia rebater com firmeza: Silveira foi por isso intimado a desistir de qualquer futura iniciativa, sob a severa ameaça de excomunhão, de 500 cruzados de multa e de um procedimento contra si. ${ }^{37}$

Aquele modelo integrado dava, em qualquer caso, os seus resultados. Desde o início dos anos cinquenta vinha sendo experimentado também no norte de África onde, para além da presença de cristãos-novos, um objetivo primário era representado pelo refrear das fugas para terra muçulmana dos convertidos apóstatas, mas também dos portugueses que aí renegavam, por necessidade ou por escolha, a fé dos antepassados. Naquele contexto, para favorecer a sua reentrada na Igreja, a Inquisição revelou-se disposta a mostrar uma face misericordiosa, reservada pelo contrário aos cristãos-novos somente no circunscrito tempo da graça que precedia a recolha de denúncias depois da leitura do édito da fé. No reino, tornara-se um limite não mais superado depois da humilhante concessão de dois perdões gerais aos cristãos-novos, imposta aos inquisidores em 1535 e em 1547 por causa da excessiva violência da sua repressão. No império, pelo contrário, a relativa fragilidade do poder político lusitano constringiu os juízes da fé a seguir muitas vezes um modelo capaz de atrair os fiéis que tinham errado, sem que a ameaça do castigo os dissuadisse. A sua origem vai individuada na provisão enviada a 21 de julho de 1550 pelo inquisidor geral a todos os vigários gerais e oficiais da justiça eclesiástica "dos lugares d'Africa", nos quais se fixavam as etapas que garantiriam aos convertidos apóstatas e aos renegados um percurso protegido pelo segredo da confissão sacramental no momento do retorno a terra cristã, seguida então de um registo de forma privada, perante o Santo Ofício de

\footnotetext{
${ }^{35}$ Sobre este ponto permito-me reenviar para o meu livro: MARCOCCI, Giuseppi. I custodi dell'ortodossia. Inquisizione e chiesa nel Portogallo del Cinquecento. Roma: Edizioni di Storia e Letteratura, 2004, p. 160-175.

${ }^{36}$ O peculiar modelo da Madeira levou a um equilíbrio entre o delegado da Inquisição e o bispo do Funchal: em 1556, o novo antístite, o frade Jorge de Lemos, recebeu dos inquisidores de Lisboa o mandato de prisão contra o cristão-novo Jorge Lopes para que o transmitisse ao juiz civil da Madeira (ANTT. IL, liv. 840, fl. 18v).

${ }^{37}$ Provisão inquisitorial de 10 de junho de 1551 (ivi, fl. 8). A infração de Silveira consistia talvez em proceder em nome de uma delegação inquisitorial que nunca tinha recebido.
} 
Lisboa, da ocorrida reconciliação. ${ }^{38}$ Ao mesmo tempo, fez-se recurso também aos jesuítas ativos além da fronteira com o mundo islâmico. A iniciar uma tradição de confiança e de estreitas relações entre missionários e inquisidores no Império português esteve o padre João Nunes. Munido de licença do cardeal infante d. Henrique, recolheu então em Tetuão o fruto do seu zelo de evangelizador também mediante a absolvição de um número impreciso de arrependidos que se tinham tornado judeus ou muçulmanos. ${ }^{39}$ Eram os primeiros sinais de uma dupla estratégia que caracterizaria a história da presença inquisitorial nos territórios do Império português: foi o resultado não só de um tratamento diverso reservado aos diferentes tipos de heresia, mas também - talvez, sobretudo - da capacidade política variável do domínio lusitano nos distintos contextos coloniais.

O encaminhamento do processo de expansão extra-europeia do tribunal da fé verificou-se em paralelo à saída em estampa dos primeiros volumes das crônicas oficiais das conquistas portuguesas em África e Ásia (Fernão Lopes de Castanheda, 1551; João de Barros, 1552). Aquelas edições foram a data de nascimento de uma disciplinada literatura imperial, na qual se refletia a nova ordem de uma cultura agora capaz de recompor, numa visão unitária, a experiência colonial lusitana. Daquele movimento geral participou também o Santo Ofício. As marcas de uma gestão centralizada da Inquisição do ultramar aparecem com toda a evidência a quem desfolha o registo do tribunal de Lisboa em que foram recolhidas em conjunto as minutas das correspondências enviadas aos agentes delegados fora da Europa. Aquele registo, do qual retirei os dados apresentados nas páginas precedentes, abre-se com a comissão enviada à Madeira em $1550 .^{40}$ Assim permite seguir, durante os anos 1550, o lento consolidar de um modelo para o império idealizado no reino, através das instruções sobre a reintegração

${ }^{38}$ Provisão inquisitorial de 21 de julho de 1550 (ivi, cc. 5-6), em que se sublinhava a importância de agir "com muita caridade e benignidade". Para um aprofundamento ver BRAGA, Isabel M. R. M. Drumond. Entre a cristandade e o Islão (séculos XV-XVII). Cativos e renegados nas franjas de duas sociedades em confronto. Ceuta: Instituto de Estudios Ceutíes, 1998.

${ }^{39}$ Uma relação encontra-se na carta de António de Quadros a Inácio de Loyola, escrita de Lisboa a 16 de março de 1554 (Litterae Quadrimestres. Madrid-Roma: A. Avrial-Administratio-IHSI, 1894-1932, vol. 2, doc. 280). Sobrevive uma cópia de um decreto inquisitorial sem data, no qual se regulava a obra de Nunes (PEREIRA. Documentos, doc. 26). Este último, além disso, figurava entre os vinte e nove jesuítas a que, a 22 de maio de 1551, o geral Loyola confere ad personam a faculdade de absolver por heresia in foro coscientiae (Monumenta Ignatiana. Series prima. Sancti Ignatii de Loyola, Societatis Iesu fondatoris, epistolae et instructiones. Madrid: G. López del Horno, 1903-1911, vol. 3, doc. 1820).

${ }^{40}$ Trata-se do códice que tem por título Livro em que se registão as provisões que vão para fora (ANTT. IL, liv. 840). Aí se encontram também disposições sobre localidades do reino sob a jurisdição da Inquisição de Lisboa. 
de apóstatas e renegados, as normas para impedir o contato entre convertidos e infiéis, as ordens de captura, as dispensas. ${ }^{41}$ Sempre no seu interior encontrase a primeira provisão na qual se ordenava o denunciar ao Santo Ofício quem infringisse a proibição sancionada pelo direito canônico e pela bula In coena Domini de vender aos infiéis armas, metais, madeira e outras mercadorias que podiam ser usadas na guerra contra os cristãos (1550). ${ }^{42}$ Sem uma competência direta sobre aquele delito, o tribunal procurava assim estender a sua autoridade sobre uma esfera de importância vital no mundo português: o comércio nas colônias. Tratou-se, de qualquer modo, de um elemento dissuasor, de uma ameaça de natureza simbólica mais do que real, como se deduz do número exíguo de processos celebrados depois que a Coroa acordou aos inquisidores a jurisdição na matéria. ${ }^{43}$ No registo da Inquisição de Lisboa conserva-se, por fim, o Regimento de 1554 para o tribunal de Goa, testemunho da primeira tentativa de abrir uma sede ultramarina, sob pedido também dos missionários franciscanos e jesuítas. ${ }^{44}$ Aquelas normas refletiam também a recente elaboração do primeiro Regimento geral do Santo Ofício (1552). ${ }^{45}$

A atividade quotidiana dos juízes de Lisboa foi um fator que influiu nas escolhas adotadas. Não foi irrelevante, por exemplo, que, no mesmo decênio em que o Santo Ofício lançou as próprias bases para além dos confins do reino, aqueles mesmos inquisidores puderam criar uma opinião pessoal dos problemas religiosos nas diferentes áreas do império graças à abertura de causas não apenas por delitos de cripto-judaísmo cometidos pelos cristãos-novos fugidos nas colônias, mas também por crimes de outro tipo. Assim acontece com o grupo de mouriscos libertos que ganhavam a vida na Ribeira de Lisboa, acusados em 1550 de atentar

${ }^{41}$ Assinalo a carta de 28 de novembro de 1552 ao vigário geral de Tânger para autorizar o regresso em terra cristã de pesssoas que habitavam em Tetuão (ivi, fl. 15v); o decreto inquisitorial de 21 de maio de 1557 sobre a vigilância da entrada de judeus e muçulmanos em Tânger e Ceuta (fl. 20rv); os mandatos de prisão de 19 e 22 novembro 1558, enviados respectivamente ao bispo de Angra para que fizesse prender Jorge Dias, mercador de Ponta Delgada, e ao vigário geral de Tânger para que capturasse o cristão-novo Rui Mendes (fl. 25v); o inquérito de 20 de novembro de 1559 ao bispo de Cabo Verde para ratificar os testemunhos contra os acusados Manuel Dias e sua mulher (fl. 29).

${ }^{42}$ Provisão inquisitorial, 25 de setembro de 1550 (ivi, fls. $6 v-7 v$; agora em PEREIRA. Documentos, doc. 13).

${ }^{43}$ Alvará régio, 1 de fevereiro de 1552 (ivi, doc. 21). Foi concedido à Inquisição para punir alguns agentes comerciais do banqueiro Luca Giraldi, processado ele mesmo, sem consequências, entre 1553 e 1555 (PEREIRA, Isaías da Rosa. Lucas Giraldi, um mercador florentino na Inquisição de Lisboa. Anais da Academia da História Portuguesa, $2^{\mathrm{a}}$ s., 28, 1982, p. 287-314). O alvará também declarou de competência inquisitorial o delito de entrar em terra muçulmana sem licença.

${ }^{44}$ BAIÃO. A Inquisição de Goa, vol. 1, p. 27. Para um seu enquadramento na história do advento do tribunal na Índia ver CUNHA. A Inquisição, p. 129-130 (ivi, p. 290-295).

${ }^{45}$ BAIÃO. A Inquisição em Portugal e no Brasil, doc. 31. 
contra a fé de neófitos muçulmanos que nem sequer sabiam falar português. ${ }^{46} \mathrm{De}$ 1553 datam também os processos contra três escravos wolof provenientes da Senegâmbia, onde tinham recebido uma rudimentar educação islâmica, para depois serem batizados em Portugal, embora se possam nutrir fortes dúvidas, tendo por base os autos judiciários, sobre o seu real conhecimento das várias passagens de identidade religiosa. ${ }^{47}$ Entre 1557 e 1558, finalmente, foram apresentadas aos inquisidores de Lisboa as primeiras denúncias contra escravos de origem indiana. ${ }^{48}$ Aquelas experiências contribuíram também para dar substância à dimensão imperial que desde então constituiria um novo horizonte da Inquisição lusitana.

\section{Inquisidores e missionários: provas de entendimento (c. 1560-1575)}

A seguir uma reorganização da administração eclesiástica no Império (em 1557 foram criadas as dioceses de Cochim e de Malaca, sujeitas à autoridade da Sé de Goa, elevada a arquidiocese), a segunda fase de expansão da Inquisição teria continuado a andar em torno aos bispos e seus oficiais, mas foi marcada por uma relação sempre mais orgânica entre inquisidores e missionários, em particular jesuítas. A rápida difusão destes últimos na Índias orientais e no Brasil ofereceria às autoridades do reino, às quais a Companhia estava já solidamente ligada, a ocasião para dar uma nova roupagem formal à jurisdição do Santo Ofício nas terras do ultramar. ${ }^{49}$

A colonização lenta e contrastada do Brasil desaconselhava então a tentativa de introduzir um tribunal na América. Mas, no entanto, a Inquisição reforçou o seu controle. O bispo da Bahia, Pedro Leitão, residia no reino. Não podendo tomar parte de alguns processos em curso em Lisboa contra fiéis da sua diocese (erigida em 1549), resolveu-se a indicar o inquisidor Ambrósio Campelo como seu substituto na qualidade de ordinário também para as causas futuras. Tal decisão foi tomada em 1559, dois anos depois da chegada ao Brasil de um governador com um passado de inquisidor, Mem de Sá, que guiaria, com o auxílio dos padres jesuítas, uma agressiva campanha militar contra os índios que opunham resistência. ${ }^{50}$

${ }^{46}$ ANTT. IL, proc. 1636. O processo, conduzido pelos inquisidores Gonçalves Ribafria e Campelo, desenrolou-se entre junho e julho de 1550 e concluiu-se com penas leves.

${ }^{47}$ SAUNDERS, A. C. de C. M. A social history of black slaves and freedmen in Portugal, 14441555. Cambridge: Cambridge University Press, 1982, p. 158-164.

${ }^{48}$ Assim interpreto o termo "índio" nas denúncias resumidas em BAIÃO. A Inquisição em Portugal e no Brasil, p. 177, 179.

${ }^{49}$ Sobre a expansão da Igreja no Império português ver BETHENCOURT, Francisco. A Igreja. In: História da expansão portuguesa, vol. 1, p. 369-386.

${ }^{50}$ A comissão de 10 de maio de 1559 encontra-se editada em PEREIRA. Documentos, doc. 81. Sobre 
Assim, o primeiro verdadeiro teatro de uma sistemática colaboração entre inquisidores e missionários foi Goa, a capital do Império português na Ásia, onde as todavia instáveis condições de um domínio fixado no controle dos maiores entrepostos comerciais ao longo das rotas da navegação no oceano Índico permitiu instituir, em 1560, o primeiro grande tribunal extra-europeu na história das Inquisições. ${ }^{51} \mathrm{~A}$ decisão foi tomada depois que uma campanha judiciária desencadeada contra os cristãos-novos de Cochim, com o empenho ativo do jesuíta Gonçalo da Silveira, tinha levado à transferência dos presos para Lisboa e à abertura de processos por cripto-judaísmo. ${ }^{52}$ À diferença do Brasil, de fato, o objetivo de perseguir os judaizantes foi a razão principal da penetração do Santo Ofício na Índia, ainda que há tempo que o tribunal era invocado também para impedir que os convertidos locais fossem assediados pelos antigos correligionários. ${ }^{53}$ As instruções da nova Inquisição previam procedimentos moderados para os "cristãos da terra", como eram chamados os neófitos de origem hindu ou muçulmana, mas não se acolheram os pedidos de repetir nos trópicos o exemplo seguido no reino com os judeus na altura do batismo forçado, quando se lhes concedeu uma imunidade de vinte anos para os delitos de fé..$^{54}$

Alcançou-se assim uma geografia institucional destinada a não sofrer mudanças. $\mathrm{O}$ tribunal de Lisboa consagrou-se à própria vocação atlântica, enquanto

a governação de Mem de Sá, cf. WETZEL, Herbert Ewaldo. Mem de Sá, terceiro governador geral (1557-1572). Rio de Janeiro: Conselho Federal de Cultura, 1972. Com a provisão de 12 de junho de 1541, o infante d. Henrique, inquisidor-mor, tinha nomeado Sá como substituto para a arquidiocese de Lisboa no caso da sua ausência (Biblioteca da Ajuda [BdA], cod. 54-X-17, n. 7). Limita-se a assinalar a sua assinatura no final dos autos de um processo daquele mesmo ano. FARINHA, Maria do Carmo Jasmins Dias. Ministros do Conselho Geral do Santo Ofício. Memória, 1, 1989, p. 101-206: 105.

${ }^{51}$ O único precedente era aquele do efêmero tribunal aberto pela Inquisição espanhola no norte de África, entre 1516 e 1525, sobre o qual ver ACERO, Beatriz Alonso. L'Inquisition espagnole à la frontière de berbérie. Oran-Mazalquivir, XVI ${ }^{\mathrm{ème}}$ et XVIII ${ }^{\mathrm{ème}}$ siécles. In: Inquisição em África, p. 65-82.

${ }^{52}$ CUNHA. A Inquisição, p. 131-139.

${ }^{53}$ Assim já fazia Francisco Xavier numa carta escrita a Francisco Mansillas a 7 de abril de 1545 (SCHURHAMMER, George e WICKI, Josef (ed.). Epistolae S. Francisci Xaverii aliaque eius scripta. Roma: Institutum Historicum Societatis Iesu, 1996, vol. 1, doc. 50).

${ }^{54}$ Pediu-o o jesuíta Melchior Carneiro na missiva a Francisco Borja de 6 janeiro de 1555 (DI, vol. 3, doc. 65). Pelo contrário, os capítulos para a Inquisição de Goa, de 2 de março de 1560 - chegados à Índia alguns meses depois, junto com os novos inquisidores, Aleixo Dias Falcão e Francisco Marques Botelho, acompanhados pelo primeiro arcebispo, Gaspar de Leão Pereira -, conferiram aos cristãos da terra apenas a isenção quinquenal do confisco dos bens, além do privilégio de evitar, no final do primeiro processo, a reconciliação formal e a abjuração, que eram tidas apenas em caso de reincidência, "justo ate se aver provisão pera não serem relapsos senão quamdo parecer aos inquisidores” (incluídos também em ANTT. IL, liv. 840, fls. 5-8, 2ª num., são editados por BAIÃO. A Inquisição de Goa, vol. 1, p. 30-35; e CUNHA. A Inquisição, p. 295-301). 
que o mundo que se abria a este do cabo da Boa Esperança ficou reservado para a autoridade do novo tribunal inquisitorial instaurado em Goa, criado também para superar as ineficiências de uma justiça episcopal que também se ocupara de judaizantes nos decênios precedentes (em 1543, o bispo franciscano Juan Alfonso de Albuquerque chegou até a publicar a bula da Inquisição no dia seguinte à queima do cristão-novo Jerónimo Dias). ${ }^{55}$ No primeiro vintênio de atividade no Estado da Índia, o Santo Ofício reprimiu duramente aqueles conversos que tinham seguido as direções dos negócios portugueses na Índia, o outro grande ponto de chegada dos itinerários marranos nas colônias ibéricas, ao lado das possessões na América estudadas por Nathan Wachtel (mas no Brasil foi somente entre os séculos XVII e XVIII que a Inquisição desencadeou uma maciça perseguição contra os descendentes dos judeus convertidos). ${ }^{56}$

Chegados de Portugal, os inquisidores de Goa encontraram-se perante uma sociedade fervilhante de crenças, línguas e costumes, que tornavam incertas as fronteiras no interior do Império lusitano nas Índias orientais. Missões e Inquisição tornaram-se assim nas duas faces, nem sempre fáceis de distinguir, de uma política fundada sobre a conversão das populações locais, com prevalência para hindus e muçulmanos. A aceitação do catolicismo impõe-se como a via principal para a integração civil na sociedade colonial lusitana, debaixo da pressão de um proselitismo cada vez mais agressivo, destinado à extirpação total das diferenças religiosas de localidades como Goa, Bardez e Salsete, segundo formas em parte inspiradas na anulação de qualquer sinal exterior das antigas minorias religiosas em Portugal entre finais do século XV e inícios do século XVI. Um complemento daquela estratégia foi o intenso controle sobre a fé dos convertidos que o Santo Ofício acabou por exercitar. E, todavia, apesar da destruição dos templos, a proibição dos cultos e festas locais em público, os grandes batismos solenes e uma legislação discriminatória direcionada para favorecer os neófitos, o programa de evangelização, partilhado por tantos servidores daquela que foi, em todos os efeitos, uma Igreja militante, mas também pelas autoridades da Coroa, revelouse superior aos excepcionais esforços profusos. ${ }^{57}$ Disto oferecem numerosos testemunhos as fontes inquisitoriais.

${ }_{55}$ Sobre a bula do Santo Ofício promulgada em Goa em 1543 cf. BAIÃO. A Inquisição de Goa, p. 263-264. A primeira queima de um judaizante remonta a 1539 (CUNHA. A Inquisição, p. 126-127).

${ }^{56}$ WACHTEL, Nathan. La foi du souvenir. Labyrinthes marranes. Paris: Seuil, 2001, a complementar com QUEVEDO, Ricardo Escobar. Inquisición y judaizantes en América española, siglos XVI-XVII. Bogotá: Editorial Universidad del Rosario, 2008.

${ }^{57}$ Para Goa e territórios limítrofes, cf. MENDONÇA, Délio de. Conversions and citizenry. Goa under Portugal, 1510-1610. Nova Dehli: Concept Publishing, 2002; XAVIER, Ângela Barreto. 
Os inquisidores, assistidos muitas vezes por deputados provenientes das ordens regulares, num primeiro momento dominicanos e jesuítas (mas também franciscanos e, mais tarde, agostinhos) atacaram de imediato os cristãos da terra. ${ }^{58}$ Já no primeiro auto da fé, que teve lugar no interior da catedral de Goa em 1562 , ressoaram as abjurações dos convertidos de origem hindu. ${ }^{59}$ Ainda mais frequentes seriam aquelas por cripto-islamismo, a começar pelas pronunciadas pelo georgiano Abraham e pelo armênio Cobar Gorgi, sempre em 1562. ${ }^{60}$ As condenações à morte foram, no entanto, reservadas para os cristãos-novos. As primeiras remontam a 1563 . Se não nesse momento, certamente no ano seguinte os jesuítas prestaram o conforto aos justiçados, uma atividade de contornos judiciários nada irrelevantes se as confissões feitas aos sacerdotes antes de subirem ao patíbulo fossem transformadas em revelações para uso dos inquisidores. ${ }^{61}$ A dupla identidade de juízes e assistentes espirituais (os jesuítas ocuparam-se também da reeducação dos condenados a penas menores) caracterizou em Goa uma figura típica do mundo português, o "missionário-inquisidor", que no âmbito imperial levou à máxima expressão uma aliança entre a Companhia de Jesus e o Santo

A invenção de Goa: poder imperial e conversões culturais nos séculos XVI e XVII. Lisboa: ICS, 2008. Permito-me também reinviar para o meu estudo: MARCOCCI, Giuseppe. Costruire un outro Portugal. Strategie di conversione a Goa fra Cinque e Seicento. In: CAFFIERO, Marina (ed.). Forzare le anime. Conversioni tra volontà e costrizione in età moderna. Atti del convegno internazionale. Rivista di Storia del Cristianesimo, 7, 2010 (no prelo).

${ }^{58}$ Seguidamente, foram regulares também entre os inquisidores: o primeiro foi o dominicano Gaspar de Melo, nomeado em 1583. Um elenco dos juízes e dos deputados da Inquisição de Goa encontra-se em BAIÃO. A Inquisição de Goa, vol. 1, p. 163-178. Útil também CUNHA. A Inquisição, p. 151-166.

${ }^{59}$ Biblioteca Nacional de Portugal [BNP], cód. 203, passim. Sobre a importância desta fonte ver TAVIM, José Alberto R. S. Um inquisidor inquirido: João Delgado Figueira e o seu Reportório, no contexto da documentação sobre a Inquisição de Goa. Leituras. Revista da Biblioteca Nacional, 1 , 1997, p. 183-193. Para uma panorâmica geral sobre a documentação do tribunal de Goa, sobretudo conservado na Torre do Tombo, ver CUNHA, Ana Cannas da. A Inquisição de Goa. Notas de estudo. CONFERÊNCIA INTERNACIONAL VASCO DA GAMA E A ÍNDIA. Atas. Lisboa: Fundação Calouste Gulbenkian, 1999, vol. 3, p. 59-70, a integrar com o catálogo dos códices guardados na Biblioteca Nacional do Rio de Janeiro: MORENO, Carmen Tereza Coelho (coord.). Inquisição de Goa: inventário analítico. Anais da Biblioteca Nacional, 120, 2000 [2006], p. 7-272.

${ }^{60}$ BNP, cód. 203, fls. 94 e 212. Os dois foram então enviados para o reino, como se conclui também da carta dos inquisidores de Goa para o inquisidor geral Henrique de 23 de dezembro de 1562 (BAIÃO. A Inquisição de Goa, vol. 1, p. 38-45).

${ }^{61}$ Para aprofundamento permito-me reenviar para o meu estudo: MARCOCCI, Giuseppe. La salvezza dei condannati a morte. Giustizia, conversioni e sacramenti in Portogallo e nel suo impero, 1450-1700 ca. In: PROSPERI, Adriano (ed.). Misericordie. Conversioni sotto il patibolo tra Medioevo ed età moderna. Pisa: Edizioni della Normale, 2007, p. 189-255. Aos condenados que não falavam português, os padres aproximavam-se através de tradutores, como informava Sebastião Fernandes na carta ao geral Borja de finais de Novembro de 1569 (DI, vol. 8, doc. 12). 
Ofício tornando-se então cada vez mais sólida no reino (até se reservar em 1571 um lugar permanente no Conselho Geral para um padre jesuíta).$^{62}$

Aquele modelo, encarnado na Goa dos anos 1560 por António de Quadros e por Francisco Rodrigues, seria depois difundido, talvez com sensíveis diferenças, no resto do império: em 1571, o jesuíta Antonio Monserrate, em viagem da Europa para a Índia (de onde seria depois levado em missão com Rodolfo Acquaviva à corte do Grão Mogol), chegou até a lançar um mandato de prisão na fortaleza de Mazagão, no norte de África, contra o agostinho Sebastião Saavedra, que conseguiu no entanto salvar-se fugindo para território muçulmano. ${ }^{63}$ Enquanto se perseguia com dureza crescente os cristãos-novos, entre os anos 1560 e 1570, o tribunal de Goa constitui um laboratório onde foram experimentadas novas estratégias de ação, acompanhadas de uma precoce tentativa de adoptar os decretos do Concílio de Trento, em que, porém, as questões missionárias tinham encontrado um espaço bastante reduzido. ${ }^{64}$ Como na América, às práticas religiosas dos hindus foi aplicada a etiqueta de "idolatria", mas não faltaram casos classificados como feitiçaria. ${ }^{65} \mathrm{O}$ primeiro, em ordem de tempo, foi aquele de uma javanesa de Cochim, batizada com o nome de Violante, condenada em 1565 a abjurar perante os inquisidores de Goa a culpa de "chupar mininos e ter ajuntamento por vezes com o diabo" ${ }^{66}$ No seu complexo, a de Goa foi sobretu-

${ }^{62}$ Para os casos do reino remeto o leitor para o meu artigo: MARCOCCI, Giuseppe. Inquisição, jesuítas e cristãos-novos em Portugal no século XVI. Revista de História das Ideias, 25, 2004, p. 247-326. Com a expressão "missionário-inquisidor" refiro-me ao tipo de missionário ao serviço do Santo Ofício, quer como inquisidor ou deputado, quer como visitador ou comissário.

${ }^{63}$ BAIÃO. A Inquisição em Portugal e no Brasil, p. 282.

${ }^{64}$ REGO, António da Silva. Trent's impact on the Portuguese patronage missions. Lisboa: Centro de Estudos Históricos Ultramarinos, 1969. Em Bassein, em 1573, o respeito pelos decretos do concílio provincial de Goa foi imposto pelo inquisidor Bartolomeu da Fonseca (DI, vol. 9, doc. 61).

${ }^{65}$ Para a América espanhola ver BERNAND, Carmen e GRUZINSKI, Serge. De l'idolatrie. Une archéologie des sciences religieuses. Paris: Seuil, 1988.

${ }^{66}$ BNP, cód. 203, fl. 638v. Já um ano antes o moçambicano António tinha tido uma condenação por adivinhação (ivi, fl. 96v). Entre os casos coevos destaca-se aquele de uma escrava birmanesa batizada, declarada culpada em 1574 de ter feito um pacto com o demônio "a quem deu sangue da mão esquerda, lhe aparecia e tinha com ella aiuntamento e por cuia ordem soube e usou feitiçarias e estando prenha lhe matou o demonio a criança" (ivi, fl. 389v). Faltam estudos sobre Inquisição e feitiçaria na Índia, à diferença do que sucede para o Brasil (SOUZA, Laura de Mello e. O diabo e a Terra de Santa Cruz. Feitiçaria e religiosidade popular no Brasil colonial. São Paulo: Companhia das Letras, 1987; EAD. Inferno atlântico. Demonologia e colonização, séculos XVI-XVIII. São Paulo: Companhia das Letras, 1993; PIMENTEL, Helen Ulhôa. Universo mágico colonial. Feiticeiros e inquisidores nos dois primeiros séculos da colonização do Brasil. Tese de doutorado apresentada na Universidade de Brasília, 2005) e África (CALAINHO, Daniela Buono. Africanos penitenciados pela Inquisição portuguesa. In: Inquisição em África, p. 47-63; HAVIK, Philip. La sorcellerie, l'acculturation et le genre: la persécution religieuse de l'Inquisition portugaise contre les femmes africaines converties en Haut Guinée (XVII siècle), ivi, p. 99-116). Para uma 
do uma Inquisição de fronteira. Por isso, como no norte de África, também nas Índias orientais se ofereceu aos convertidos a possibilidade de uma reentrada doce na Igreja, protegida por procedimentos secretos nos quais estava prevista a colaboração de missionários e clero diocesano. Se necessário, aquela solução podia ser adoptada até em Lisboa: por exemplo, o sacerdote Lourenço Afonso, acabado de regressar a Portugal da Índia, talvez tenha tido um papel decisivo na comparência de um escravo indiano (1566), fugido em terra muçulmana onde havia apostatado. ${ }^{67} \mathrm{Em}$ geral, para remediar os frequentes episódios de fuga para além das fronteiras, se promulgaram éditos de graça válidos por seis meses a favor de quem em "terra de infiéis" tinha feito o retorno à própria religião de origem. ${ }^{68}$ Precoces foram, finalmente, os processos abertos contra hindus e muçulmanos não batizados, acusados de dificultar as conversões dos seus correligionários, ou de atentar contra a frágil fé dos neófitos. ${ }^{69}$ Por vezes, aquelas causas judiciárias resolveram-se com a concessão do perdão em troca do batismo, como acontece com o naique Vitul, que tentara consignar um jovem convertido a um muçulmano. Processado em 1568, evitou o castigo só porque se converteu juntamente com toda a sua família. ${ }^{70}$ No ano seguinte, sob parecer positivo da Mesa da Consciência e Ordens - tribunal especial encarregado de exprimir-se sobre decisões régias em matéria de competência eclesiástica - a Coroa autorizou de forma oficial aqueles procedimentos contra os infiéis na Índia. ${ }^{71}$

síntese geral ver PAIVA, José Pedro. Inquisizione e stregoneria in Portogallo nella prima età moderna. In: CORSI, Dinora e DUNI, Matteo (eds.). "Non lasciar vivere la malefica". Le streghe nei trattati e nei processi (secoli XIV-XVII). Firenze: Firenze University Press, 2008, p. 115-127.

${ }^{67}$ BAIÃO. A Inquisição em Portugal e no Brasil, p. 222.

${ }^{68}$ A estratégia baseada no édito da fé extenso e sobre a reconciliação secreta foi sancionada pelas instruções do inquisidor geral Henrique a 13 de fevereiro de 1576 (Idem. A Inquisição de Goa, vol. 1, p. 295-300), em resposta a questões solevadas de Goa. Ilustra-se o procedimento observado, no qual estavam envolvidos, de maneira especial, confessores da Companhia de Jesus, na carta do inquisidor Fonseca de 8 de novembro de 1576 (ivi, vol. 2, doc. 5). Uma confirmação da parte jesuítica na carta de Duarte de Sande ao geral Claudio Acquaviva de 5 de dezembro de 1583 (DI, vol. 12, doc. 142).

${ }^{69}$ Os primeiros quatro, movidos contra mercadores hindus em 1565 , resolveram-se com a absolvição por ausência de provas (BNP, cód. 203, fls. 177v, 353, 557).

${ }^{70}$ BNP, cód. 203, fl. 639v. O mesmo ocorreu, em 1575, a um hindu de Salsete (ivi, fl. 105), enquanto três anos antes o brâmane Loku Sinay foi condenado a açoites e a cinco anos nas galés "por induzir os cristãos a se fazerem gentios" (ivi, fl. 442v). Ainda em 1587, um hindu de Salsete de nome Rama foi perdoado em troca da conversão, depois de ter sido processado por convencer alguns catecúmenos de Goa a fugirem para terra muçulmana (ivi, fl. 593v).

${ }^{71}$ A sentença de 2 de março de 1569, assinada por Martim Gonçalves da Câmara, Gonçalo Dias Carvalho, Jerónimo de Valadares, os jesuítas Miguel de Torres e Leão Henriques e os dominicanos António Bernardes e António de São Domingos, recitava: “Tem Sua Alteza obrigaçaõ de castigar gravemente, e mandar inquirir dos que por si, ou por outro, directè, ou indirectè, por obra, ou por 


\section{A Inquisição portuguesa, um tribunal para o mundo (ca. 1575-1600)}

Os processos da Inquisição de Goa na segunda metade de Quinhentos abraçam uma variedade única de acusados, entre os quais convertidos originários de regiões compreendidas entre o Corno de África e a China, para além dos "armênios" (adjetivo muitas vezes usado para indicar pessoas provenientes da área da Alta Mesopotâmia) que, como se verá, foram vítimas de uma campanha especial de perseguição. ${ }^{72}$ Nos primeiros dois decênios de atividade, o alvo principal do tribunal continuou a ser os europeus, portugueses sobretudo (cristãos-novos, mas também aqueles colonos que sentiram a atração dos cultos locais), mas não só, considerada a presença não esporádica de protestantes entre os condenados. ${ }^{73}$ Em qualquer caso, depois que foi assegurada uma ampla jurisdição sobre os indianos, foram estes últimos a ocupar sempre os inquisidores de Goa, que talvez escolheram moderar os procedimentos, num esquema geral de vigilância que só em casos excepcionais revelou aos convertidos os traços mais agressivos do tribunal. Tratou-se mais do que outra coisa de gerir e conter as tensões de um ambiente em risco de explosões de violência e de revolta. A Inquisição tendeu a assumir funções de polícia dos costumes, ao objetivo de proibir as cerimônias e manifestações exteriores reconducentes à religião de origem dos neófitos. ${ }^{74}$ Sobretudo na região de Goa, circundada como estava de formações políticas hostis que, com a sua simples existência, alimentavam sentimentos de resistência ao domínio dos portugueses (exígua minoria em relação à população local), foi necessário encontrar compromissos e evitar, se possível, o uso de castigos públicos de resultados imprevisíveis (escolha partilhada também pelos missionários jesuítas). A decisão de não celebrar autos da fé entre os anos 1580 e 1590 resultou de avaliações como as que chegavam ainda do reino, uma vez constatado que

palavra impedem o negocio da conversaõ: e parece que se deve mandar fazer diligencia sobre isto ordinariamente pelos Inquisidores da India" (MENESES, Manuel de. Chronica do muito alto e muito esclarecido D. Sebastião decimosexto Rey de Portugal... Segunda parte. Lisboa Occidental: na Officina Ferreyriana, 1730, p. 88).

${ }^{72}$ A amplitude da geografia humana objeto da perseguição da Inquisição de Goa emerge de condenações como aquela infligida por cripto-hinduísmo à escrava bengalesa Isabel em 1565 (BNP, cód. 203, fl. 385v), por cripto-islamismo ao escravo chinês Francisco em 1578 (ivi, c. 308v), por palavras contra a fé cristã ao chinês Basílio Vaz em 1595 (ivi, c. 191), além do duplo processo por cripto-islamismo contra um escravo abissínio de Chaul, que tinha nome cristão de Gabriel, hoje conservado na Torre do Tombo (ANTT. IL, proc. 4937).

73 Já em 1562 (carta supra citada n. 60), eram referidas as prisões de "luteranos" franceses, sublinhando "que he couza mui importante á pureza e á conservação da fee nom passar cá nenhum estrangeiro".

${ }^{74}$ Emblemática uma carta de 1579 na qual se invocam soluções contra os "ritos no publico em forma de festas e casamentos de costume das gentes" (BAIÃO. A Inquisição de Goa, vol. 2, doc. 14). 
a maior parte dos processos se referia aos cristãos da terra, a alguns mestiços e a portugueses fugidos para terra de infiéis: "tereis muita conta de não tratardes com muito rigor os novamente convertidos por se não escandalisarem os gentios e se impedir a conversão delles nestas partes". ${ }^{75}$

Assim, apesar da primeira queima em efígie de um condenado por criptohinduísmo, o mestiço Luís Pereira (1587), a condição de instabilidade permanente, agravada pela expansão do Império mogol, e a desilusiva experiência de campo dos missionários induziram os inquisidores a pedir com cada vez mais insistência a faculdade de evitar a condenação à morte para os convertidos relapsos, uma escolha que se reclamava abertamente do exemplo seguido pela Inquisição espanhola com os moriscos. ${ }^{76} \mathrm{~A}$ sua concessão foi muitas vezes discutida na regular correspondência que, com cadência anual, o tribunal de Goa trocava com as autoridades centrais do Santo Ofício de Lisboa. Só depois de muitos esforços, em 1559, ao tempo da união dinástica entre Espanha e Portugal, a Congregação romana do Santo Ofício conferiu o poder de absolver nas Índias orientais os neófitos reincidentes no delito de heresia. ${ }^{77}$ Confirmado cada cinco anos, daquele privilégio fez-se um uso frequente, que permite explicar, frente

${ }^{75}$ Carta do cardeal arquiduque Alberto d'Austria, inquisidor geral, aos inquisidores de Goa, 24 de março de 1589 (cit. $i v i$, vol. 1, p. 420). De uma missiva do ano seguinte se retirava que, em 1588, não se realizou o auto-da-fé porque os penitenciados eram quase todos "homens da terra" (ivi, vol. 1, p. 269). Sobre a posição dos jesuítas cf. a carta de Francisco Fernández para Acquaviva de 15 de outubro de 1593 (DI, vol. 16, doc. 39).

${ }^{76}$ Recordou-se, numa carta de Lisboa de 1587 , na qual se informava o inquisidor de Goa, Rui Sodrinho de Mesquita, de se terem encontrado breves análogos a favor dos moriscos do reino de Aragão (ivi, vol. 1, p. 266-269). Aquele poder tinha sido concedido na primeira metade dos anos 1530 aos inquisidores de Valencia (CÁRCEL, Ricardo García. Herejía y sociedad en el siglo XVI. La Inquisición en Valencia, 1530-1609. Barcelona: Península, 1980, p. 29). Da Índia pedia-se aquele poder pelo menos desde a carta de 3 de janeiro de 1569 ( $i v i$, vol. 2, doc. 1). Sobre a sentença capital contra Pereira ver BNP, cód. 203, fl. 450. Uma breve referência na carta dos inquisidores de Goa, Sodrinho de Mesquita e frei Tomás Pinto, ao inquisidor geral Alberto de 2 de dezembro de 1587 (BAIÃO. A Inquisição de Goa, vol. 2, doc. 25). O peso do estado de guerra, especialmente depois do cerco de Goa por parte das tropas do sultão de Bijapur (1570-1571), incide sobre o funcionamento do tribunal, como se denunciava numa carta de 1574 (ivi, vol. 2, doc. 2).

${ }^{77}$ Breve Sedes Apostolica de 22 de janeiro de 1599 (In: Corpo diplomatico portuguez contendo os atos e relações politicas e diplomaticas de Portugal com as diversas potências do mundo desde o século XVI ate aos nossos dias. Lisboa: Academia Real das Sciencias, 1862-1959, vol. 12, p. $77-$ 79). Sobre a deliberação do Santo Ofício romano ver Archivio della Congregazione per la Dottrina della Fede [ACDF], Decreta S.O. 1597-1598-1599, c. 229). Os cardeais inquisidores tinham-se expressado uma primeira vez em sentido negativo, em 1595, como informava Filipe II numa carta ao Conselho Geral de 5 de fevereiro de 1596 (PEREIRA, Isaías da Rosa. A Inquisição em Portugal, séculos XVI-XVII. Período filipino. Lisboa: Vega, 1993, doc. 5). Pode-se imaginar a dificuldade criada pela grande demora se se pensar que, desde as instruções de 1576, o inquisidor geral Henrique tinha ordenado a suspensão das causas de relapsos, na espera do breve (doc. supracitado, n. 68). 
ao número extremamente alto de processos contra convertidos indianos nos dois séculos sucessivos, a raridade das sentenças capitais. Além disso, deveuse fornecer uma interpretação alargada (de fato, dever-se-ia considerar apenas "os neófitos descendentes dos gentios e dos infiéis"), a ter em conta do caso de Francisco Rangel, um mestiço de origem portuguesa residente na vila de Cortim, nos arredores de Goa: depois de um primeiro processo por cripto-hinduísmo em 1592, em 1605, enfrentou uma nova causa pelo mesmo crime, mas sai com uma condenação a abjuração e ao exílio (o uso da faculdade de absolver os relapsos foi pois aprovado pelo Conselho Geral) ${ }^{78}$

Pouco atenta até então aos territórios do Império português, alguns decênios antes a Congregação romana do Santo Ofício não tinha mostrado tanta relutância em relação aos índios da América convertidos (jamais sujeitos à ação direta da Inquisição espanhola), a favor dos quais, em 1577, tinha concedido à Companhia de Jesus importantes privilégios em matéria de casamento. ${ }^{79} \mathrm{Um}$ reflexo daquela diversa sensibilidade dos principais inquisidores em relação às Índias Ocidentais se pode colher talvez na solução, adotada dois anos mais tarde pelo novo inquisidor geral português, Jorge de Almeida, de reservar ao bispo da Bahia, António Barreiros, e aos padres jesuítas (em particular, Luís da Grã) a gestão dos eventuais casos de heresia entre os índios convertidos, recomendando particular moderação "para que se não intimIdem os outros". Tratava-se, por um lado, de uma ratificação das funções de proteção que o prelado e os missionários já praticavam com respeito às autoridades civis e aos colonos, que arriscavam virar, para seu próprio proveito, a arma do Santo Ofício. Por outro lado, era o resultado de uma reorganização das estratégias de controle religioso estendidas a uma rígida repartição entre as competências dos inquisidores (cristãos-novos judaizantes e outros cristãos europeus responsáveis por crimes contra a fé) e aquelas do bispo (neófitos), observando que, no tocante aos casos que tocavam à Inquisição, ele não teria "mais jurisdição que a que tem como prelado". ${ }^{80}$ Aquele esquema tentava

${ }^{78}$ BNP, cód. 203, c. 327v. Baião (A Inquisição de Goa, vol. 1, p. 8) escreve que o breve Sedes Apostolica reconheceu um poder exercitado só de maneira descontínua; na realidade, foi confirmado constantemente e estava ainda em vigor no tempo de Inocêncio XI (ACDF, St. St. LL 4-h, c. 133).

${ }^{79}$ Faculdade concedida a 17 de julho de 1577 (ACDF. St. St. D 4-f, c. 80).

${ }^{80}$ Provisão de 12 de fevereiro de 1579 (PEREIRA. Documentos, doc. 52). O acordo entre o bispo da Bahia e os jesuítas sobre a estratégia a seguir com os índios, consolidada no ano precedente no confronto sobre as condições de tratamento destes últimos (LEITE, Serafim. História da Companhia de Jesus no Brasil. São Paulo: Edições Loyola, 2004, ${ }^{2}$ vol. 1, p. 72), foi sublinhado com força pelo prelado num certificado de 26 de março de 1582 (ivi, vol. 1, p. 422). Ignora a provisão WADSWORTH, James E. Jurema and Batuque: Indians, Africans and the Inquisition in colonial Northeastern Brazil. History of Religions, 46/2, 2006, p. 140-162, em que se reconstrói uma tenta- 
superar os limites de ação do tribunal lusitano no mundo atlântico (aspecto que poderia ter contribuído a fazer dele um espaço de maior tolerância, se se partilha a proposta de Stuart Schwartz), mesmo num momento de reorientação geral do eixo central do Império português do oceano Índico para a América, a luz da qual se compreende também o impulso para a expedição militar em Marrocos, concluída com a morte em batalha do rei d. Sebastião em Alcácer-Quibir (1578) ${ }^{81}$ Aquele acontecimento, que abriu uma crise dinástica destinada a resolver-se com a assunção da coroa de Portugal pela parte de Filipe II (1580), teve repercussões imediatas sobre o Santo Ofício, e não apenas pela alternância à frente do tribunal da fé a seguir à saída para o trono do ancião cardeal d. Henrique. A rota do exército de d. Sebastião, com a queda em mão muçulmana de centenas de guerreiros, determinou uma renovada atenção ao norte de África por parte da Inquisição: a necessidade de gerir os retornos de quantos tinham renegado a fé cristã levou as autoridades centrais do Santo Ofício a redefinir as normas para a sua absolvição, com o pleno envolvimento dos vigários diocesanos das praças portuguesas, mesmo nos próprios dias em que se emitia a referida provisão a favor do bispo da Bahia. ${ }^{82}$

Se ali se fez um uso imediato desta última não se sabe, mas os poderes de Barreiros e do jesuíta Grã foram prontamente desafiados pelo movimento da "santidade de Jaguaripe", estudado por Ronaldo Vainfas: já nos anos 1580, de fato, tomou corpo às portas da Bahia um movimento de rebelião de milhares de índios, guiados pelo profeta António, um índio batizado pelos jesuítas. Além de muitos escravos fugitivos, aderiram também alguns portugueses. A revolta foi definitivamente reprimida pelo governador do Brasil, Manuel Teles Barreto, em $1585 .{ }^{83}$ Seis anos mais tarde chegou à Bahia o primeiro visitador inquisitorial da história do Brasil, Heitor Furtado de Mendonça, encarregado de uma inspeção que, segundo as primeiras instruções, devia depois tocar as principais localidades portuguesas do mundo atlântico. ${ }^{84}$ Assistido constantemente pelos jesuítas,

tiva do século XVIII de recorrer à Inquisição contra os cultos locais de índios e escravos africanos.

${ }^{81}$ A referência em corpo de texto é de SCHWARTZ, Stuart B. All can be saved. Religious tolerance and salvation in the Iberian Atlantic world. New Haven: Yale University Press, 2008.

${ }^{82}$ Provisão inquisitorial para os provisores e vigários gerais "dos lugares da Africa" de 9 de fevereiro de 1579 (PEREIRA. Documentos, doc. 51), acompanhada por uma comissão para os inquisidores de Lisboa, emitida no mesmo dia (ivi, doc. 50). Ambos os documentos, como a patente a favor do bispo da Bahia e dos jesuítas missionários no Brasil, foram assinadas pelos deputados do Conselho Geral e passadas em nome de "el rei como Inquisidor Geral".

${ }^{83}$ VAINFAS, Ronaldo. A heresia dos índios. Catolicismo e rebeldia no Brasil colonial. São Paulo: Companhia das Letras, 1997. Outra leitura em METCALF, Alida C. Millenarian slaves? The Santidade de Jaguaripe and slave resistance. American Historical Review, 104, 1999, p. 1531-1559.

${ }^{84}$ Depois da Bahia, a visita de Furtado de Mendonça limitou-se às capitanias de Pernambuco, Itamaracá e Paraiba, evitando tocar, na via de retorno, nos arquipélagos de São Tomé e Príncipe e 
o visitador ocupou-se dos clamorosos casos do decênio precedente, mas evitou com cuidado indagar os índios. ${ }^{85}$

Apesar da extrema diversidade de soluções, aqueles episódios denunciavam uma preocupação nova para a Inquisição que, a partir de então, foi cada vez mais atenta a contrariar a ameaça de uma contaminação religiosa que nos trópicos já não tocava só aos convertidos, mas aos próprios portugueses. Mais uma vez, o terreno de maior experimentação foi a Índia. Condenados a exemplares penas públicas no decorrer dos grandiosos autos da fé (até o ano de 1600, as sentenças capitais foram mais de oitenta), em Goa, como em Portugal, misericórdia e procedimentos secretos foram pontualmente negados aos cristãos-novos judaizantes. Apesar da substancial falência da proibição de livre circulação no império que lhes foi imposta em 1567, o alarme de cripto-judaísmo parece subitamente esgotar-se nos princípios dos anos 1580, como sublinharam mais de uma vez as cartas então enviadas pelos inquisidores de Goa às autoridades centrais em Portugal. ${ }^{86}$ Talvez fosse também por isso que nos mesmos meses em que a Coroa promulgava um ineficaz édito de expulsão dos cristãos-novos da Índia, se isentou o tribunal de Goa da obrigação de consultar o Conselho Geral antes de emitir sentenças, garantindo assim uma maior autonomia e rapidez de intervenção (1585). ${ }^{87}$ Foi então que, ao lado dos cristãos da terra punidos pelos

de Cabo Verde, com base no que foi ordenado pelo Conselho Geral na carta de 1 de abril de 1593 (In: BAIÃO, António. Correspondência inédita do inquisidor geral e Conselho Geral do Santo Ofício para o primeiro visitador da Inquisição no Brasil. Brasília, 1, 1942, p. 543-551, p. 548).

${ }^{85}$ Para a bibliografia sobre a primeira visita ao Brasil ver a introdução a VAINFAS, Ronaldo (org.). Confissões da Bahia. Santo Ofício da Inquisição de Lisboa. São Paulo: Companhia das Letras, 1997. Peculiar a análise de AUFDERHEIDE, Patricia. True confessions: The Inquisition and social attitudes in Brazil at the turn of the XVII century. Luso-Braziliane Review, 10, 1973, p. 208-240.

${ }^{86}$ Em novembro de 1580, o inquisidor de Goa, Fonseca, denunciava ao inquisidor geral Jorge de Almeida que o "o negocio da India do Santo Offiçio dos christãos novos" estava esgotado (BAIÃO. A Inquisição de Goa, vol. 2, doc. 19). Sobre os números da perseguição até 1600, cf. BOYAJIAN. Goa Inquisition, p. 7-8. Para os decênios seguintes, ver Idem. Portuguese trade in Asia, p. 174-184. Tendo por base um alvará régio de 2 de novembro de 1567 (ANTT. IL, mç. 31, doc. 4, num. 3 devo o seu conhecimento a Hugo Crespo), cabia aos inquisidores conceder derrogações no caso de delito de circulação no império estabelecido por provisão de 30 de junho de 1567. Casos de concessão de tais licenças, entre 1567 e 1570, são registados em ANTT. IL, liv. 840, fls. 73-80v. A 15 de março de 1568, foi emanado um novo alvará régio que proibia a entrada na Índia sem licença (BAIÃO. A Inquisição de Goa, vol. 1, p. 315). Um quadro sobre as restrições à circulação de cristãos-novos em CARNEIRO, Maria Luiza Tucci. Preconceito racial em Portugal e no Brasil colônia. Os cristãos-novos e o mito da pureza do sangue. São Paulo: Perspectiva, 2005, p. 74-88.

${ }^{87}$ Assim estabelecia uma provisão inquisitorial de 31 de março 1573, confirmada em 1583, quando se pretendia também o envio de nove processos específicos para submeter a revisões processuais (BAIÃO. A Inquisição de Goa, vol. 1, p. 288-289, 308-312). Sobre a inaplicabilidade do édito de expulsão de 1585 cf. BOYAJIAN. Goa Inquisition, p. 5. 
crimes mais graves com açoites e as galeras, encontraram cada vez mais lugar também aqueles portugueses acusados de terem aderido aos ritos e crenças de origem hindu, uma ocorrência nada rara a julgar pelos processos abertos pelo culto e pela oferta de sacrifícios às divindades locais, por exemplo para conhecer o futuro. Também naquele caso se tentou cominar castigos que não comportassem infâmia pública. Estava em risco, de fato, a mesma imagem do poder imperial que era difundida pela retórica oficial dos representantes da Coroa, eles mesmos implicados em algumas causas judiciárias, cujo início se coloca na fase inicial das tensões com as autoridades civis que tinham tenazmente constelado a história da Inquisição de Goa. ${ }^{88}$ Em 1589, foi colocada ao inquisidor geral a questão de como comportar-se com os portugueses que "tratam misticamente com feiticeiros gentios" ${ }^{89}$ A resposta fornecida marcou uma viragem no último, atormentado, decênio de Quinhentos:

Acerca das pessoas que consultam os pagodes dos gentios, e lhes offereçe[m] offertas e presentes, e tratam com os bramenes e feiticeiros gentios, que se inquira meudamente dellas e, sendo suas culpas de modo que pertençao ao Santo Officio por serem notoriamente heresias, ou que sapiant haeresim manifeste, se castiuem conforme a ellas com o rigor e severidade que os casos requerem, e achando que pertencem somente ao ordinario, e não ao Santo Officio, os poderão remetter $[\ldots]^{90}$

No ano seguinte, por aquele delito foram abertos processos contra vários portugueses, inclusivamente contra o governador da Índia, Manuel de Sousa Coutinho, e parte da sua família. ${ }^{91}$ Mas a vigilância sobre as formas híbridas da religiosidade colonial voltou-se também na direção oposta, como mostra a denúncia de um culto local que surgiu em torno à estátua de Afonso de Albuquerque, colocada junto ao sepulcro do antigo governador, nos arredores da cidade.

${ }^{88}$ Sobre conflitos com o vice-rei e governadores e mais, em geral, com as outras autoridades locais ver BAIÃO. A Inquisição de Goa, vol. 1, p. 53-162. Um caso de Seiscentos está no centro do recente estudo de CANNAS, Ana. Fé e poder: o conflito entre a Inquisição de Goa e o vice-rei António de Melo de Castro (1663-1670). In: BARRETO, Luís Filipe et al. Inquisição portuguesa. Tempo, razão, circunstância. Lisboa-São Paulo: Prefácio, 2007, p. 257-275.

${ }^{89}$ Carta de 20 de novembro de 1589 (BAIÃO. A Inquisição de Goa, vol. 2, doc. 27).

${ }^{90}$ Carta do inquisidor geral Alberto, 20 de março de 1591 (ANTT. Conselho Geral do Santo Ofício [CGSO], liv. 298, p. 103-104; ANTT. CGSO, liv. 100, c. 47v; também em Lembranças particulares, determinações e resposta que se enviaram por cartas de S.A. e Conselho Geral a esta Inquisiçam de Goa as quaes servem de Regimento nella. ANTT. CGSO, liv. 207, c. 289v.).

${ }^{91}$ Descrevi este acontecimento na conferência Élites imperiali e culti locali. Usi politici del sincretismo religioso nella Goa di fine Cinquecento, apresentada no seminário internacional de estudo Sola una ley se tenga: hacia una nueva historia de las minorias en el mundo ibérico (Pisa, 15-16 dezembro 2008). 
Em 1593, os inquisidores perguntaram a Lisboa como se deveriam comportar e expressaram o temor de que hindus e convertidos julgassem aquela estátua como a imagem "de algum santo e como tal fazerlhe reverencia". ${ }^{92} \mathrm{O}$ Conselho Geral limitou-se a ordenar aos juízes que transmitissem o caso ao arcebispo. ${ }^{93}$

\section{Características da Inquisição no mundo português em finais de Quinhentos}

No seu conjunto, o funcionamento institucional do Santo Ofício no mundo português na segunda metade de Quinhentos foi estruturado no sistema da delegação do poder inquisitorial aos representantes de uma cada vez mais extensa rede eclesiástica. Dado o espaço imenso da sua jurisdição, o tribunal de Goa encontrou-se a recorrer de imediato àqueles agentes, apoiando-se também nas autoridades seculares, como mostra o decreto com que, em 1566, o vice-rei da Índia, Antão de Noronha, obrigou a todas as embarcações destinadas à capital que transportassem os suspeitos heréticos presos pelos bispos de Cochim e de Malaca, pelos vigários ou pelos administradores espirituais de outras localidades. ${ }^{94}$ A assistência das autoridades episcopais foi então decisiva também no norte de África e nas ilhas atlânticas, da Madeira aos Açores, de Cabo Verde a São Tomé, também se não faltaram casos nos quais a Inquisição de Lisboa recorreu aos magistrados civis. ${ }^{95}$ Seja como for, nas diversas regiões do império instaurou-se uma confiança cada vez maior nos missionários que, graças à cobertura do seu hábito, prometiam penetrar profundamente no segredo dos corações dos convertidos (também no Brasil, embora com menor intensidade).

Nem sempre os religiosos de que o Santo Ofício se serviu tinham recebido mandato oficial; pelo menos no caso dos jesuítas, pode-se imaginar que foi assim também para evitar enervar ulteriormente as autoridades centrais romanas que, da Casa Geral, se opunham à entrega de encargos oficiais aos padres por parte da Inquisição de Goa. ${ }^{96}$ Ainda mais, escolher dominicanos, franciscanos e

${ }_{92}$ Carta de 22 de novembro de 1593 (BAIÃO. A Inquisição de Goa, vol. 2, doc. 33).

${ }_{93}$ Carta de 8 de fevereiro de 1595 (ANTT. CGSO, liv. 100, fl. 62).

${ }^{94}$ Decreto de 6 de abril de 1566 (BAIÃO. A Inquisição de Goa, vol. 1, p. 293-294), recordado também no primeiro estudo de fundo sobre o uso da delegação por parte do tribunal indiano: FEITLER, Bruno. A delegação de poderes inquisitoriais: o exemplo de Goa através da documentação da Biblioteca Nacional do Rio de Janeiro. Tempo, 24, 2008, p. 127-148: 134-135.

${ }^{95}$ Vários exemplos em ANTT. IL, liv. 840. Permanece inexplorado o tema da colaboração dos tribunais seculares com a Inquisição portuguesa: na cartas enviadas aos juízes civis de Cabo Verde (1563), Tânger (1565 e 1566) e Madeira (1570), encontra-se notícia (ivi, cc. 41, 44v, 47v e 58 , respectivamente).

${ }^{96}$ A estreita colaboração dos jesuítas com a Inquisição de Goa, a que se opunha já Borja em finais dos anos 1560 (DI, vol. 7, doc. 68), foi criticada em vão pelos gerais Everardo Mercuriano e 
jesuítas como comissários tinha a vantagem de permitir uma mais ágil revogação da nomeação em caso de necessidade, diferentemente do que podia ocorrer com respeito às autoridades diocesanas, no caso de que tivessem reivindicado a tradicional competência no terreno do controle da fé. Em relação a estas últimas, de resto, não faltavam razões de desconfiança: do arrastar das causas abertas contra expoentes do poder ordinário (o administrador de Ormuz, Nicolau Pais, nos anos setenta de Quinhentos; o vigário geral de Goa, Duarte Ramalho Botelho, em finais do século) aos casos de evidente falta de confiança (como o vigário de São Tomé, Gonçalo da Silva, denunciado em 1589 pelos cônegos da catedral por ter libertado heréticos), até ao conflito jurisdicional, entre os séculos XVI e XVII com os bispos de Malaca e de Macau (diocese criada em 1576) e até com o arcebispo de Goa (neste último caso pelo direito de julgar quem violava a proibição de vender armas e mercadorias proibidas aos infiéis). ${ }^{97}$ As tensões cresceram sobretudo no tempo do cisterciense Leonardo de Sá (1578-1599), o primeiro ordinário a residir na China. De Goa observava-se que a escolha de nomear comissários para Malaca e para Macau dependia do fato de que "as [scil. as diligências] farião milhor e com mais cuidado e brevidade que os bispos". 98 Precisamente na última das duas cidades rebentava o confronto entre o agostinho Miguel dos Santos, vigário geral indicado por Aleixo de Meneses, o arcebispo de Goa (também ele agostinho), e o jesuíta Valentim de Carvalho, novo comissário

Acquaviva, bem como por Alessandro Valignano, sobretudo entre os anos 1570 e 1580 (os documentos mais significativos encontram-se em ivi, vol. 10, doc. 20; vol. 11, doc. 89; vol. 12, doc. 138; vol. 13, docs. 1, 34; vol. 14, docs. 63, 125). Sobre a aversão a que os padres se revestissem do cargo de comissário cf. a carta de 20 de novembro de 1591, na qual o provincial Pedro Martins procurava justificar a Acquaviva a nomeação de António Marta nas Molucas (ivi, vol. 15, doc. 95).

97 Em 1572, Pais foi condenado a abjuração privada diante do tribunal de Goa por ter dito que "a fornicação simplex não era peccado" (BNP, cod. 203, fl. 545). Em 1575, foi aberto um novo inquérito a seu cargo, baseado em algumas frases suspeitas reportadas pelo dominicano Gaspar da Cruz (BAIÃO. A Inquisição em Portugal e no Brasil, p. 284). Do caderno de denúncias contra Ramalho Botelho por corrupção e abuso do ofício, recolhido em 1597, mostrava-se também a existência de frições processuais com a Inquisição (ANTT. IL, proc. 4.941, fls. 127-134v; tratase, na realidade, de um maço que contém autos judiciários contra diversos acusados, enviados de Goa para Lisboa para receberem instruções, dada a sua especial delicadeza). Uma súmula da denúncia contra Silva pode ler-se em BAIÃO. A Inquisição em Portugal e no Brasil, p. 238. Quatro anos antes, em Goa, foi condenado a abjurar o sacerdote Francisco da Zurara, que tinha escoltado de Macau uma cristã-nova presa pelo Santo Ofício, por ter mostrado a transcrição das inquirições que tinha feito a terceiros, (BNP, cod. 203, fl. 312v). Sobre a ciosa defesa das faculdades de absolvição da heresia por parte dos bispos de Malaca e de Macau - mas também foram movidas acusações ao bispo de Cochim, André Fernandes - ver FEITLER. A delegação, p. 135-138. Sobre o confronto de 1616 com o arcebispo dominicano Cristóvão de Sá e Lisboa cf. BAIÃO. A Inquisição de Goa, vol. 1, p. 66.

${ }^{98}$ Carta para o inquisidor geral Pedro de Castilho, 15 de dezembro de 1605 (ivi, vol. 2, doc. 76). 
do Santo Ofício. ${ }^{99}$ A uma solução estável não se chegou senão alguns anos mais tarde com a chegada de um bispo dominicano, João de Abrantes da Piedade, a quem a Inquisição de Goa devia acordar a patente de comissário sem demora, dada a harmonia e acordo entre a ordem dos pregadores e o tribunal da fé. ${ }^{100} \mathrm{Um}$ modelo análogo foi seguido tempo depois com o bispo de Funai (diocese erigida em 1588), o jesuíta Diogo Correia Valente, que obteve a patente de comissário do Santo Ofício no Japão em 1619. ${ }^{101}$

Era o êxito de um longo caminho no qual não tinham faltado acidentes de percurso, sobretudo com os jesuítas, lacerados também na Ásia pela controvérsia sobre a admissão de cristãos-novos na Companhia, um ponto a que os inquisidores não eram certamente indiferentes, como foi evidente quando Nuno Rodrigues, o reitor do colégio de Goa, tentou fazer nomear deputado do Santo Ofício o suspeito cristão-novo Duarte de Sande (1580). ${ }^{102}$ De seguida, levantou escândalo na cidade, constrangendo a Inquisição a um chamamento público, o caloroso acolhimento oferecido no mesmo colégio a um mercador condenado por cripto-judaísmo justamente na noite em que saiu do cárcere. Estava-se em 1593 e o principal responsável daquele gesto desafiante foi Gomes Vaz, um jesuíta de origem conversa. ${ }^{103}$ Não se pode descurar o fato de que, uma vez rompida no reino a colaboração entre o Santo Ofício e a Companhia, substituída pelo privilégio de um lugar no Conselho Geral da ordem dominicana (1614), foi precisamente na Índia que se celebraram os primeiros processos contra jesuítas. ${ }^{104}$

${ }^{99}$ Um memorial sobre o acontecimento encontra-se em BdA, cod. 49-V-5, fls. 56-67v.

${ }^{100}$ Patente de 18 de abril de 1611 (copia ivi, c. 116rv). Cf. também a carta do bispo de Macau aos inquisidores de Goa de 15 de abril de 1613 (In: BAIÃO. A Inquisição de Goa, vol. 2, doc. 115). A 25 de janeiro de 1615, saiu também a primeira intervenção da Congregação romana do Santo Ofício sobre a China, com a concessão aos jesuítas de celebrarem missa de cabeça coberta e com um barrete especial e de traduzir a Bíblia "in lingua sinarum non tamen vulgari, sed erudita et literatorum propria", a mesma que se permitia usar aos sacerdotes chineses nos ofícios divinos (ACDF. St. St. LL 4-h, fl. 560).

${ }^{101}$ Patente de 11 de maio de 1619 (cópia da BdA, cód. 49-V-5, fl. 282rv). Em qualquer caso, Valente não regressou nunca à sua diocese, mas permaneceu até à sua morte em Macau.

${ }^{102}$ Carta de Lourenço Pinheiro ao geral Mercuriano, 28 de outubro de 1580 (DI, vol. 12, doc. 17). O mesmo Pinheiro, que talvez servisse de deputado da Inquisição de Goa segundo o que se lê numa carta de 1577 do inquisidor Fonseca (BAIÃO. A Inquisição de Goa, vol. 2, doc. 9), estava envolvido na suspeita de ser cristão-novo (DI, vol. 11, doc. 97).

${ }^{103} \mathrm{O}$ episódio é referido com abundância de pormenores na carta de Alberto Laerzio a Acquaviva de 28 de novembro de 1593 (DI, vol. 16, doc. 66). Juntamente com Sande, Vaz era há algum tempo alvo de pressões por causa da sua linhagem (cf. ivi, vol. 11, docs. 85, 97; vol. 12, docs. 4, 27, 72, 120).

${ }^{104}$ Depois da admoestação oficial no tribunal imposta ao jesuíta Tomé Barreto em 1615 por ter afirmado que "a correa de São Paulo podia tirar huma alma do inferno o que Christo não podia" (BNP, cod. 203, fl. 634), a 4 de julho de 1618, o jesuíta Bartolomeu Cabral pronunciou a abjuração na capela do Santo Ofício por ter favorecido um herético (ivi, fl. $205 v$ ). Sobre o não linear percurso 
Em qualquer caso, entre os missionários e os inquisidores de Goa, foram raros os casos de confronto. Os jesuítas por vezes promoveram finalmente a prisão de hindus, como aconteceu em Salcete, a sul de Goa, com um perturbador de conversões "tido em tanta estima, que lhe bebião a agoa com que lavava os pés". ${ }^{105}$ Entre a população local, entretanto, serpenteava um sentimento de hostilidade e de intolerância para com os padres da Companhia. Salsete tinha sido palco de um dos êxitos mais trágicos, quando em Cuncolim, em 1583, foram massacrados cinco jesuítas no decurso de uma sublevação antiportuguesa. ${ }^{106}$ Menos de dez anos depois, um grupo misto de convertidos e de hindus aí tomou de assalto uma igreja administrada por um padre da Companhia. Foi de imediato a Inquisição a intervir para restabelecer a ordem pública, com golpes de prisões e de abjurações na praça: "el fruto principal que destos trabajos se sacó", comentou entusiasta um jesuíta, "fue bautizarse la aldea de Betalbati", que en Salsete era para la gentilidad como para los ereges la Rochela en Francia". ${ }^{107}$ Naquelas palavras se vislumbra a maturação de uma sensibilidade comum a missionários e inquisidores derivada também do envolvimento dos primeiros nos controles sobre os procedimentos do tribunal graças a periódicas visitas oficiais, mas também inquéritos secretos sobre a conduta dos juízes. Ao dominicano Gaspar de Melo foi confiada a primeira inspeção da sede de Goa no mesmo ano em que aí tinha assumido as funções de inquisidor (1583). ${ }^{108}$ Oito anos depois, a visitar o tribunal indiano esteve pelo contrário o jesuíta Pedro Martins, figura de grande crédito junto das autoridades centrais de Lisboa que, com antecedência, o tinham encarregado de redigir um relatório reservado sobre o inquisidor Rui Sodrinho de Mesquita (1586). ${ }^{109}$

Paralelamente a Goa, também se registou um labor de supervisão no Brasil, onde Furtado de Mendonça conduziu uma visita inquisitorial que partiu da Bahia, em 1591, para depois terminar, quatro anos mais tarde, em Pernambuco. ${ }^{110}$ Foi censurado pelas autoridades centrais que se opuseram à sua tentativa de se

que conduziu a ordem dos pregadores a instaurar uma relação privilegiada com a Inquisição, cf. PAIVA, José Pedro. Os dominicanos e a Inquisição em Portugal (1536-1614). In: PALACIOS, Arturo Bernal (ed.). Los dominicos y la Inquisición en el mundo ibérico e ispanoamericano. Roma: Istituto Storico Domenicano, 2006, p. 505-573.

${ }^{105}$ Littera Annua da província da Índia, 7 de novembro de 1594 (DI, vol. 16, doc. 117). Aí se refere também uma prisão igualmente em Salsete, que se concluiu com o batismo do hindu processado pela Inquisição e de toda a sua família.

${ }^{106}$ XAVIER. A invenção de Goa, p. 333-367.

${ }^{107}$ Littera Annua da província da Índia, 30 de novembro de 1591 (DI, vol. 15, doc. 102).

${ }^{108}$ BAIÃO. A Inquisição de Goa, vol. 1, p. 324.

${ }^{109}$ Ivi, vol. 1, p. 197.

${ }^{110}$ Sobre o seguimento da visita cf. MELLO, José Antônio Gonçalves e. Um tribunal da Inquisição em Olinda, Pernambuco (1594-1595). Revista da Universidade de Coimbra, 36, 1991, p. 369-374. 
transformar num verdadeiro inquisidor, com faculdades para emitir sentenças contra qualquer heresia (enquanto que os seus poderes lhe permitiam fazê-lo só por bigamia, blasfêmia e outros delitos menores). ${ }^{111} \mathrm{~A}$ assídua presença de padres da Companhia a seu lado não constituiu apenas um auxílio prestado por religiosos mais conhecedores da sociedade local, mas agiu também de travão às intemperanças de um visitador pouco inclinado a respeitar as regras em matéria de prisões: talvez tenha sido o temor de uma injusta captura a levar Estêvão da Rocha a atentar contra a vida de Furtado de Mendonça atirando-lhe dois golpes de arcabuz; só a mediação dos jesuítas conseguiu evitar que o visitador se vingasse punindo o colono da Bahia com a morte por fuzilamento. ${ }^{112}$

Muitas vezes projetadas e depois não realizadas, as visitas inquisitoriais foram uma arma frequentemente utilizada entre os séculos XVI e XVII para expandir o raio de ação do Santo Ofício no Império português. ${ }^{113}$ Foram depois substituídas pela criação de uma rede de comissários, ou pelo conferimento aos mesmos missionários de inspeções sobre a observância da fé e da moralidade dos costumes. Foi um sucesso precoce. De resto, até que excessos poderia levar-se um inquisidor em visita a uma localidade do império demonstrou-o então António de Barros, inquisidor de Goa. Chegou a Ormuz em 1595, regressado de um duro confronto que o tinha oposto ao colega Sodrinho de Mesquita sobre o tratamento reservado para os cristãos da terra apóstatas - este último defendia a absolvição imediata, enquanto que Barros pretendia submetê-los pelo menos a um breve processo. ${ }^{114} \mathrm{Na}$ ilha à entrada do Golfo Pérsico, florescente centro econômico e lugar de convivência entre povos, o visitador exibiu toda a sua intransigência. Atacou com inaudita violência hindus e convertidos, acusados de estarem unidos numa "mistica conversação" e de venerarem "feitiços": a sua atuação levou à prisão de alguns bengalenses indigentes, expulsos de seguida porque julgados inúteis à cidade, enquanto que os guzerates de Khambhat, ativos no comércio das pérolas, conseguiram escapar às perseguições, protegendo o seu templo. ${ }^{115}$

\footnotetext{
${ }^{111}$ Carta do Conselho Geral de 13 de janeiro de 1592 (BAIÃO. Correspondência, p. 544-545).

${ }^{112} \mathrm{O}$ episódio é referido numa carta de José de Anchieta a Miguel de Azevedo, capitão da Bahia, 1 de dezembro de 1592 (PEIXOTO, A. (ed.). Cartas, informações, fragmentos históricos e sermões do padre Joseph de Anchieta, S. J., 1554-1594. Rio de Janeiro: Civilização Brasileira, 1933, doc. 26). A conversão da pena capital em degredo foi moderada pelo Conselho Geral que disso informou Furtado de Mendonça numa carta de 1 de abril de 1593 (BAIÃO. Correspondência, p. 547-548). Tinha já repreendido os seus procedimentos na missiva de 24 de outubro de 1593 (ivi, p. 545-546).

${ }^{113}$ Sobre as visitas efetuadas, ou somente projetadas, no Estado da Índia cf. Idem A Inquisição de Goa, vol. 1, p. 324-325.

${ }^{114}$ Sobre o conflito entre Barros e Sodrinho (1593-1595) cf. ivi, vol. 2, docs. 39-48.

${ }^{115}$ Carta de Barros ao inquisidor geral Alberto, 18 de dezembro de 1595 (ivi, vol. 2, doc. 52). Evitou,
} 
No final de Quinhentos, os jesuítas ao serviço dos inquisidores constituíram uns dos principais fatores de unidade das estratégias de vigilância da fé no mundo português, da Índia ao Brasil. A visita inquisitorial a Angola, em 1596, foi a primeira a ser confiada directamente a um padre da Companhia, Jorge Pereira. ${ }^{116}$ Jesuíta era também Jerónimo Xavier que, em 1600, se encontrava em missão no Império mogol, dotado de autoridade pelo Santo Ofício para conceder aos apóstatas que encontrasse até um ano de tempo para se dirigirem ao tribunal de Goa e pedirem perdão. Em Lahore, encontrou um mercador cristão-novo chamado Manuel Serrão, condenado à morte em efígie em 1577: assim, voltou-se para os inquisidores para receber instruções a fim de obter a faculdade de o absolver no local. ${ }^{117}$

Em casos mais raros, finalmente, o caminho foi traçado por missionários pertencentes a outras ordens. Em 1595, o carmelita Cipriano denunciou, à Inquisição de Lisboa, Henrique Lopes, mercador cristão-novo ativo no porto de Cachéu, então vivo centro do comércio de escravos na costa da moderna Guiné-Bissau. Acusava-o de ter vendido ao soberano não cristão da vizinha Bichangor um escravo negro depois de o fazer batizar. ${ }^{118}$ No inesperado gesto do frade Cipriano colhe-se talvez uma premissa da ineficaz condenação do trato atlântico, votada, em 1686, pela Congregação romana do Santo Ofício. ${ }^{119}$ Mais concreto surge o nexo da delação do carmelita com a decisão de aproveitar da abertura da residência da Companhia de Jesus em Cachéu, em 1623, justificada com a necessidade de garantir batismos válidos para os negros africanos, para nomear um jesuíta comissário da Inquisição para vigiar os traficantes cristãos-novos. ${ }^{120}$

pelo contrário, ocupar-se da minoria muçulmana por temer retaliações da parte do Xá.

${ }^{116}$ HORTA, José da Silva. A Inquisição em Angola e Congo: o inquérito de 1596-98 e o papel mediador das justiças locais. In: Arqueologia do Estado. Primeiras jornadas sobre formas de organização e exercício dos poderes na Europa do Sul. Séculos XIII-XVIII. Lisboa: História e Crítica, 1988, vol. 1, p. 388-415.

${ }^{117}$ Cartas de Xavier à Inquisição de Goa, 10 de agosto de 1600, e dos inquisidores António de Barros e Marcos Gil Frazão ao inquisidor geral António Matos de Noronha, 22 de dezembro de 1600 (BAIÃO. A Inquisição de Goa, vol. 2, docs. 67 e 64, respectivamente). Anos antes, numa carta enviada ao geral Acquaviva a 7 de dezembro de 1593, o mesmo Xavier tinha-se alinhado contra os castigos infligidos pelo Santo Ofício aos neófitos indianos, observando que "la Inquisición en la Nueva Spanha y Perú no corre con estos nuevos christianos por sertas resones, que aún acá son más urgentes, porque allá todos son christianos y acá no, sino pocos en comparación de los gentiles" (DI, vol. 16, doc. 76). Sobre a figura de Manuel Serrão cf. BOYAJIAN. Goa Inquisition, p. 9-10.

${ }^{118}$ A denúncia encontra-se resumida em BAIÃO. A Inquisição em Portugal e no Brasil, p. 274.

${ }^{119}$ GRAY, Richard. The papacy and the Atlantic slave trade: Lourenço da Silva, the capuchins and the decisions of the Holy Office. Past \& Present, 115, 1987, p. 52-68.

${ }^{120}$ Carta do rei Filipe IV ao inquisidor geral Fernão Martins Mascarenhas, 4 de agosto de 1623 (PEREIRA. A Inquisição em Portugal, doc. 147; cf. também doc. 149). 
Muitas vezes podiam tender a confundir-se, mas missão e Inquisição permaneciam coisas de qualquer modo distintas. Antes de que o Santo Ofício disso desse plena demonstração na querela sobre os ritos malabáricos, o tratamento reservado aos cristãos de São Tomás de Kerala tornou evidente a distância que ainda as separava. ${ }^{121}$ Objeto de uma missão especial, ordenada em 1578 por Valignano, a aproximação tentada então pelos jesuítas com os fiéis da Igreja siro-malabárica representou, como escreveu Inês Zupanov, uma primeira experiência da estratégia de adaptação que caracterizaria depois a ação dos padres nos contextos mais impenetráveis do padroado português na Ásia. ${ }^{122}$ Desde há algum tempo, o controle daquela comunidade cristã oriental era um objetivo das autoridades civis e eclesiásticas portuguesas, determinadas a impor uma estreita observância do rito católico latino. Em 1558, o arcebispo de Ankamali, Mar Abraham, pastor supremo dos cristãos de São Tomás (eleito pelo patriarca caldeu da Babilônia), fora feito abjurar como herético nestoriano na catedral de Cochim e depois banido da Índia. ${ }^{123}$ Prestada obediência ao papa e confirmado em Roma no seu cargo (1565), tinha assim retomado o seu posto, lançando-se em defesa da tradicional doutrina e liturgia siro-malabárica. Com aquele prelado que se opunha às hierarquias lusitanas, os jesuítas instauraram uma relação de colaboração, encaminhando, nos finais dos anos 1570, uma obra de estudo da fé dos "cristãos da serra", como eram também chamados os cristãos de São Tomás. Guiava aquela missão o padre mulato Francisco Dionísio, reitor do colégio de Cochim (depois acossado por pesadas acusações). ${ }^{124}$ Os inquisidores de Goa não tardaram a revelar a sua hostilidade às tentativas de uma gradual superação das diferenças em matéria de cerimônias, língua e crenças.

Em 1585, foram celebrados processos inquisitoriais contra "armênios", a começar pelo sacerdote Abdel Karim, acusado, entre outras coisas, de não crer que a Virgem Maria fosse a Mãe de Deus. ${ }^{125}$ O Santo Ofício ordenou-se em bloco

\footnotetext{
${ }^{121}$ Sobre a posição assumida no início de Seiscentos pela Inquisição de Goa no amplo debate sobre os ritos malabares, para além de dados e fontes apresentadas em BAIÃO. A Inquisição de Goa, vols. 1 e 2, é fundamental a miscelânea conservada em ANTT. CGSO, liv. 207.

${ }^{122}$ ZUPANOV, Inês G. "One civility, but multiple religions": Jesuit mission among St. Thomas Christians in India, 16th-17th centuries. Journal of Early Modern History, 9, 2005, p. 284-325.

${ }^{123}$ Sobre a proveniência geográfica dos bispos "armênios" ver SCHURHAMMER, Georg. Armenian bishops in Malabar? Arquivos do Centro Cultural Português, 4, 1972, p. 41-48.

${ }^{124}$ Por ter deixado daí a pouco a Companhia foi objeto de um procedimento por heresia; foi, entre outras coisas, acusado de ter-se feito passar por inquisidor. Ver a carta de Nuno Rodrigues ao geral Mercuriano, fins de novembro de 1578 (DI, vol. 11, doc. 46).

${ }^{125} \mathrm{BNP}$, cod. 203, c. 113. Em 1586, foi, pelo contrário, absolvido da acusação semelhante à do "armênio" Barrifá que conseguiu demonstrar que nunca fora católico romano (ivi, c. 186v).
} 
ao lado daqueles jesuítas contrários à abertura ao cristianismo siro-malabárico, como Francisco Ros, apoiando o objetivo da Coroa e do episcopado português de substituir Mar Abraham por um bispo católico. Impelido por uma carta de Ros, em 1595, o inquisidor geral, d. Alberto, convidou os inquisidores de Goa a iniciarem inquéritos formais a cargo do arcebispo de Ankamali e dos seus sequazes. Assim, em abril de 1596, foram auscultados como testemunhas três jesuítas do colégio de Vaipikotta, no coração da região dos cristãos de São Tomás, entre os quais sobressaía o próprio Ros, tendo por base um aturado elenco de trinta pontos de acusações. ${ }^{126}$ Ainda numa carta de dezembro de 1599, os inquisidores recordavam o caderno de culpas recolhido contra Mar Abraham, morto dois anos antes "hereje e scismatico", segundo quanto testemunhou o arcebispo de Goa (solícito colaborador do Santo Ofício). ${ }^{127}$ Poucos meses antes, este tinha celebrado o sínodo de Diamper com o qual os cristãos de São Tomás foram dobrados à obediência a Roma. ${ }^{128}$ Àquela operação tinha oferecido um sustento também a Inquisição com uma nova campanha repressiva, distinta do uso de condenações públicas, sem moderação das penas, até à morte na fogueira infligida, a 3 de junho de 1612, a um homem originário de Tabriz, que as fontes registaram com o nome de Francisco Gonçalves, acusado de "vir da sua terra por mandado de hum Coriacos cabeça dos herejes nestorianos daquellas partes, para encinar aos christãos da serrra do bispado Dangamali, novamente trazidos a obediencia romana". ${ }^{129}$ Aclarava-se assim, com absoluta eloquência, que a rígida visão da

\footnotetext{
${ }^{126}$ ANTT. IL, proc. 4941, fls. 28-37 (todo o caderno é de extrema importância: concluído em 1632, contém culpas recolhidas pela Inquisição de Goa e enviadas a Lisboa).

${ }^{127}$ Carta dos inquisidores Barros e Gil Frazão ao inquisidor geral Matos de Noronha, 23 de dezembro de 1599 (BAIÃO. A Inquisição de Goa, vol. 2, doc. 60). Aí se dava notícia também da colocação em liberdade mediante caução de dois hindus presos em 1597 depois da visita pastoral conduzida a Diu pelo arcebispo Meneses ter descoberto "hûa nova seita dizendo que não havia mais que comer e beber, e delicias da carne, e que licitamente podia dormir pai com filha e filho com mãi et sic de ceteris pera o que se ajuntavam homês e molheres assy christãos como gentios do norte" (ivi, vol. 2, doc. 59).

${ }^{128}$ Para uma aprofundada reconstrução dos fatos aqui referidos ver SUBRAHMANYAM, Sanjay. Dom Frei Aleixo de Meneses (1559-1617) et l'échec des tentatives d'indigenisation du christianisme en Inde. Archives des Sciences Sociales des Religions, 43, 1998, p. 21-41. Útil também a síntese de MUNDADAN, A. Mathias. The St. Thomas christians and the Portuguese. In: CONFERÊNCIA INTERNACIONAL VASCO DA GAMA E A ÍNDIA. Anais. Lisboa: Fundação Calouste Gulbenkian, vol. 3, p. 7-20.

${ }^{129}$ Carta do inquisidor Gonçalo da Silva ao inquisidor geral Pedro de Castilho, 24 de dezembro de 1612 (BAIÃO. A Inquisição de Goa, vol. 2, doc. 109). Sobre aquela condenação à morte ver BNP, cod. 203, fl. 337. O processo contra Gonçalves inseria-se numa fase de recrudescimento das hostilidades, devido às fortes tensões entre as autoridades portuguesas e o arcediago de Ankamali, João da Cruz (cf. BAIÃO. A Inquisição de Goa, vol. 2, docs. 98, 113; PEREIRA. A Inquisição em Portugal, doc. 73).
} 
ortodoxia dos inquisidores, diferentemente da dos missionários, não deixava espaço a estratégias de adaptação no império lusitano.

O destino dos cristãos orientais confirmava-se uma vertente na história do controle da fé no mundo português. Na viragem da sua imagem, de potenciais aliados a suspeitos heréticos, refletia-se o trajeto que, em menos de um século, a Inquisição tinha percorrido, transformando-se num tribunal também para o império. Aquele processo de expansão, na esteira de uma caça planetária aos cristãos-novos, foi acompanhado pela maturação de uma visão global das autoridades centrais de Lisboa, para as quais a experiência do Santo Ofício de Goa constitui um laboratório privilegiado de experimentação de técnicas e procedimentos inéditos. Mas na Índia, como em outras regiões sujeitas ao poder imperial lusitano, a dimensão de fronteira constringiu os inquisidores a aprenderem a dosear a violência com a caridade, a alternarem perseguições severas com a misericórdia de uma reentrada no seio da Igreja que não comportasse um peso insustentável para os convertidos apóstatas. Em finais de Quinhentos, dois aspectos caracterizavam aquilo que seríamos tentados a classificar de "colonialismo inquisitorial": a íntima ligação entre inquisidores e missionários (dominicanos e sobretudo jesuítas) que, mesmo na indubitável complexidade, foi sem par, na frequência, difusão geográfica e pluralidade de formas; e, ao lado disso, o intenso recurso à faculdade de castigar os infiéis concedida à inquisição de Goa, um elemento que permite compreender melhor a essência daquela que as fontes do tempo habitualmente indicavam como a "conquista espiritual do Oriente". 